DEMOGRAPHIC RESEARCH

VOLUME 31, ARTICLE 13, PAGES 337-380

PUBLISHED 1 AUGUST 2014

http://www.demographic-research.org/Volumes/Vol31/13/

DOI: 10.4054/DemRes.2014.31.13

Research Article

The labour trajectories of immigrant women in

Spain: Are there signs of upward social

mobility?

Elena Vidal-Coso

Pau Miret-Gamundi

(C) 2014 Elena Vidal-Coso \& Pau Miret-Gamundi.

This open-access work is published under the terms of the Creative Commons Attribution NonCommercial License 2.0 Germany, which permits use, reproduction \& distribution in any medium for non-commercial purposes, provided the original author(s) and source are given credit.

See http://creativecommons.org/licenses/by-nc/2.0/de/ 


\section{Table of Contents}

1 Introduction 338

$2 \quad$ Theoretical perspectives and research hypotheses 341

2.1 Theoretical framework 341

$2.2 \quad$ Research hypotheses 345

$3 \quad$ Data and methods 347

3.1 The 2007 National Immigrant Survey (ENI-2007) 347

3.2 Sample description and explanatory variables 349

3.3 Methods of analysis: The labour mobility matrix and logistic 352

regression

$4 \quad$ Results 353

4.1 The occupational mobility that the migratory process entails 353

4.2 The labour mobility of immigrant women as they settled in Spain: 364 leaving the cleaning and domestic occupations

$5 \quad$ Conclusion and discussion 368

$6 \quad$ Acknowledgments 372

References 373 


\title{
The labour trajectories of immigrant women in Spain: Are there signs of upward social mobility?
}

\author{
Elena Vidal-Coso ${ }^{1}$ \\ Pau Miret-Gamundi ${ }^{2}$
}

\begin{abstract}
BACKGROUND

In Spain, foreign-born women are disproportionately employed in housework or care work, and quantitative research has shown that female migrants are disadvantaged relative to male migrants in the occupational status of their first job in Spain. However, the process that created this female penalty has not yet been explored.
\end{abstract}

\section{OBJECTIVE}

In this paper, we focus on female occupational mobility at migration and during settlement in Spain. First, we compare female and male labour mobility at migration. Second, we identify the main socio-demographic factors which increase the likelihood that the first job a foreign-born woman holds in Spain will be as a cleaner or a domestic worker. Third, we investigate female labour mobility from the time of migration, particularly trajectories that lead away from the cleaning and domestic occupations, and consider the importance of the assimilation process in occupational mobility.

\section{METHODS}

We apply quantitative methods to Spain's 2007 National Immigrant Survey (Encuesta Nacional de Inmigrantes), using descriptive (mobility matrixes) and simple and multinomial logistic regression analyses. We include the main socio-demographic, family, and migratory characteristics of immigrants in the explanatory models.

\section{RESULTS}

The results of our analysis revealed that female migrants to Spain are more likely than their male counterparts to experience occupational downgrading at the time of migration, and that $41.6 \%$ of women work in domestic services in their first job in Spain. Finally, our results have demonstrated that, although occupational immobility is common among female migrants in Spain, movement out of domestic services is possible, especially for the most assimilated immigrant women.

${ }^{1}$ Universitat Pompeu Fabra, Spain. E-Mail: elena.vidalcoso@upf.edu.

${ }^{2}$ Universitat Autònoma de Barcelona, Spain. E-Mail: pmiret@ced.uab.cat. 


\section{CONCLUSIONS}

This paper contextualises female immigration in Spain, attributing the labour market choices made by female migrants to the externalisation of domestic and cleaning occupations in private households, and to the gender segmentation of the labour market.

\section{Introduction}

Before the mid-1990s, immigration was a rare phenomenon in contemporary Spain. Since then, the country has experienced an unprecedented surge in migration, especially during the period of rapid economic expansion from 1997 to 2008. As a result, the foreign-born population increased from approximately one million in 1996 (2.7\% of total population) to over six million in 2008 (13\% of total population), according to the Spanish Municipal Register (ENI). Spain, like other countries in southern Europe, has also witnessed a wave of occupation-specific migration, especially involving women, who account for $50 \%$ of the foreign population in Spain. The growing heterogeneity of the Spanish population in terms of national origin is also reflected in the labour market. As the findings of the Spanish Labour Force Survey (SLFS) indicated, from 1999 to 2008 the number of employed immigrants increased from 599,467 to 3,405,482. Over this period, the share of immigrants out of all employed individuals in Spain rose from $4 \%$ to $17 \%$, while the share of immigrant women out of all employed women in Spain increased from $5 \%$ to $19 \%$.

However, immigrants are not equally distributed throughout the occupational structure in Spain, and there is a clear tendency for immigrants, especially immigrant women, to work in low-productivity sectors and low-skilled occupations. Bernardí and Martínez-Pastor (2010) offered some explanations for why immigrants are overrepresented in unskilled jobs in Spain. First, despite successive regularisation processes from 1995 onwards, the proportion of undocumented immigrants remained high during the economic expansion, as there was a steady flow of people entering Spain and working in the country without a proper residency permit, and who thus had limited access to skilled employment. Second, since immigration to Spain was a very recent phenomenon, newly arrived migrants could not count on strong ethnic networks to help them find a job. Third, job creation (and demand for immigrant labour) during the economic expansion was concentrated in low-productivity sectors such as construction, agriculture, tourism, domestic work, and personal care services. Bernardi and Garrido (2008) observed that the strong growth in the number of jobs starting in the 1990s also led to a polarisation of employment in Spain, with people being employed in either professional and technical occupations, or unskilled service work. They also reported 
that one in four unskilled workers is an immigrant, and one in two is female. This polarisation of the labour market has accentuated the labour complementarity process between the native and the immigrant population (Amuedo-Dorantes and de la Rica 2009), and becomes particularly clear when we focus on female migrants. Increased labour market participation by native women led to the externalisation of domestic tasks and increased demand for domestic and other personal services. A study based on the Spanish Labour Force Survey found that the number of women employed in cleaning and domestic services increased 64\% between 1999 and 2008, and that more than fourfifths (81\%) of these additional workers were immigrant women (Vidal-Coso and Miret 2013).

For different geographical contexts, most studies have found that immigrants experience downward occupational mobility upon arrival in the destination country relative to the position they had in their country of origin. For example, in the U.S., Akresh (2006, 2008) confirmed the hypothesis of Chiswick (1978) and Chiswick, Lee, and Miller (2005) that immigrants experience a U-shaped pattern during their transition from the labour market in the country origin to the labour market in the country of destination. Thus, immigrants generally experience downward mobility in the first job they take after migration, but their occupational status tends to improve with the length of time spent at the destination. In Spain, quantitative analyses on immigrant occupational mobility have only very recently been conducted (Stanek and Veira 2009; Simón, Ramos, and Sanromá 2011; and Vono and Vidal-Coso 2012). These analyses have been based on data from the 2007 National Immigrant Survey (ENI), which provides labour market information on migrants both in their country of origin and in Spain. Although all of these ENI-based studies showed that women tend to have a much lower occupational status in their first job in Spain, none has explored the process that created this female penalty, or estimated the chances that domestic workers will move on to other labour positions.

Thus, in this paper we focus on female occupational mobility at the time of migration and during the process of settling in Spain. Using data from the National Immigrant Survey (2007), which has an original sample of 8,501 women and 6,964 men, we use descriptive (mobility matrixes), multinomial, and simple logistic regression analyses to investigate three different labour mobility processes. First, we study men's and women's labour mobility at migration from their last job in their country of origin to their first job in Spain, and look at whether these individuals have improved, maintained, or experienced a decline in their position in the labour market. We consider the effects of the socio-demographic, human capital, and migratory characteristics of immigrants in explaining such movements. In the course of this process, we show that being employed in domestic or family care work is the main reason why women face a higher risk than men of initial downward mobility, even after 
controlling for other socio-demographic characteristics. Second, we focus only on foreign-born women in order to identify which socio-demographic factors increase the likelihood of having a first job in Spain in cleaning or domestic work. Finally, we investigate the labour mobility of foreign-born women in Spain by contrasting the first occupation each woman had in Spain with the position she had at the time of data collection. Here, we explore how the assimilation process (measured by the acquisition of post-migration education, cohabitation with a Spanish-born partner, regular residence in the host country, and length of time spent in Spain), as well as other sociodemographic, educational, and family characteristics; influence whether and how immigrant women move from cleaning and domestic occupations (the entry portal to employment in Spain) to other positions in the labour market.

Currently, Spain is a unique country in the European context in terms of the occupational mobility of female migrants. First, the country experienced an unprecedented volume of inward migration flows over the past 15 years; at the beginning of the current economic crisis, Spain was the OECD country with the secondlargest percentage of immigrants (after the U.S.) relative the total population (OECD 2008). Second, during the recent period of economic expansion, the Spanish labour market experienced considerable polarisation in job growth, increased demand for immigrant labour, and the subsequent segregation of foreign-born workers into unskilled positions in the Spanish labour market. Third, the specificity of Spain for the analysis of occupational dynamics of foreign-born women relies primarily on the fact that in Spain, like in the other "new" immigrant societies of southern Europe (Italy, Greece, and Portugal), foreign-born women are over-represented in employment related to "services to households" (i.e., housework or care work) (OECD 2003). All of these countries have traditionally utilised family-based care models for their dependents, but female immigrants are gradually taking over the housework and care work that was traditionally done by unpaid native women, and a new labour segmentation by gender and by country of origin is emerging (Bettio, Simonazzi, and Villa 2006). According to Anthias and Lazaridis (2000); King and Zontini (2000); and King, Lazaridis, and Tsardanidis (2000); the domestic and care sector is playing a central role in attracting independent female migrants to southern Europe. Fourth, the availability of highly appropriate statistical data in Spain makes studying occupational mobility at the time of migration possible. As we noted above, the ENI data provide retrospective information on the occupational characteristics of female immigrants living in Spain, including information on their last job prior to migration and their first job in Spain.

The main contributions of our research are as follows. First, in this paper we take advantage of a new quantitative dataset in a southern European context to study the role of the domestic and family care sectors in the gendered initial insertion of migrants into the Spanish labour market. Second, one part of our study focuses specifically on 
foreign-born women in order to identify the socio-demographic and migratory characteristics that increase the chances of entering the Spanish labour market as a domestic or care worker. Third, we extend previous research by considering workplace assimilation in southern Europe, specifically the movement of immigrant women out of initial cleaning and domestic work jobs and into other labour market positions.

\section{Theoretical perspectives and research hypotheses}

\subsection{Theoretical framework}

We start with a brief panoramic view of the main theoretical perspectives regarding immigrant labour mobility. First, the functionalism and neoclassical traditions focus on the importance of human capital as a central determinant of individual differences in labour market attainment (Becker 1962, 1964; Borjas, 1994; Chiswick and Miller 2002). This perspective maintains that, within societies and labour markets, there is no structure or segmentation that constricts social and labour mobility. However, in discussing the labour market performance of immigrants after their arrival in the host country, many authors have argued that immigrants cannot rely on human capital to the same extent as natives. This is because the skills immigrants acquired in their countries of origin may be of lower quality than human capital obtained in the host country. Skills learned in the country of origin may be difficult to transfer, especially if the immigrant has a weak understanding of the labour market norms and the language of the host society (Chiswick 1978; Chiswick, Lee, and Miller 2005; Clark and Drinkwater 2008; Kanas et al. 2012). A key factor in determining the labour market performance of new immigrants is the extent to which their education, pre-migration labour market experience, and training obtained abroad are valued at the destination (Blackaby et al. 2002; Kee, 1995; Clark and Drinkwater 2008; Kanas and Van Tubergen 2009). Moreover, other researchers stressed the importance of proficiency in the host country language in explaining the employment levels immigrants attain at the country of destination, as having better language skills increases the range of jobs in the labour market for which immigrants are qualified (Leslie and Lindley 2001; Dustmann and Fabbri 2003; Berman, Lang, and Siniver 2003; Bleakley and Chin 2004). Moreover, this theoretical perspective also states that, although the human capital of migrants is initially devalued at the destination (leading to an initial phase of downward labour mobility), this is a temporary process of adjustment to the destination society, and that migrants' disadvantages relative to natives weaken thereafter (Akresh 2006, 2008; Chiswick 1978; Chiswick, Lee, and Miller 2005). Effectively, the settlement process results in the immigrant gaining an understanding of and experience in the host 
labour market, improving her language abilities, taking advantage of opportunities to acquire education in the new country, validating her foreign education, and building her networks (Akresh 2006).

The second theoretical framework we consider is the structural or dual labour market theory, which postulates that there is a relationship between career mobility and the existing segments in the labour force, and which predicts that there will be little inter-segmental mobility - particularly upward mobility - from secondary- to primarysegment occupations (Piore, 1975, 1979; Thurow 1975). Furthermore, Piore (1979) and Kalleberg and Sorensen (1979) identified the segmentation of the labour force by the migrant status or national origin of workers. Various researchers, such as Heath and Cheung 2007, referred to an "ethnic penalty," or the process through which immigrants from a particular country of origin experience some kind of deficit in their labour performance relative to the performance of natives of a similar socio-demographic profile. National or ethnic origin and sex may stratify the potential for labour market mobility, regardless of other factors, such as human capital or previous labour experience. Therefore, ethnic minorities and women are disproportionately represented in less prestigious jobs, and have greater obstacles to upward mobility (Ekberg 1994, 1996 and Rooth and Ekberg 2006 for the Swedish context). As Reyneri and Fullin (2011) noted, the segmented assimilation theories reject the hypothesis that ethnic penalties might weaken over time, since an immigrant who had accepted a poor-quality job in order to reduce her job search costs might remain trapped in the secondary segment of the labour market.

The third theoretical perspective we consider here is social capital theory (Hugo 1981; Taylor 1986, 1987; Massey et al. 1993; Massey, Goldring, and Durand 1994; Massey et al. 1994; Massey et al. 2001). The starting hypothesis is that people who are socially related to current or former migrants have access to social capital, and that this increases the likelihood that they will migrate themselves (Massey 1990; Massey et al. 2001). This occurs because social capital decreases the costs and the risks of the migration, and increases the expected net returns. Once someone in a person's networks migrates, the ties of friendship and kinship are transformed into a resource for gaining access to employment at the destination, especially to "immigrant jobs," and the money this work brings (Massey et al. 1994). Massey et al. (2001) also recognised the important role of networks in the success of the household migration strategies. However, Portes and Sensenbrenner (1993) pointed out that migrant networks may have negative consequences for migrants, facilitating entry into the labour market at the destination, while also constraining occupational opportunities and labour mobility within certain sectors. In this sense, Mahuteau and Junankar (2008) confirmed the negative effect of migrant networks by finding that they lead migrants to remain in lower positions in the labour market. 
As Spain is considered one of the newer immigrant-receiving countries, most of the literature on the integration of immigrants into the Spanish labour market is also recent (e.g., Bernardi and Garrido 2008; Simón, Ramos, and Sanromà 2011; Bernardi, Garrido, and Miyar 2011; Reyneri and Fullin 2011). Indeed, studies have found that immigrants in Spain have strong and persistent disadvantages in accessing skilled occupations, even after controlling for socio-demographic characteristics (Cachón 2009; Bernardi, Garrido, and Miyar 2011). Some authors have identified a series of explanatory factors for the immigrant disadvantage, including the growing polarisation of the Spanish occupational structure (Bernardi and Garrido 2008) and the existence of a labour complementarity process between the native and the immigrant populations (Amuedo-Dorantes and De la Rica 2009). Low-skilled labour demand and the underground economy play key roles in shaping immigrants' labour market integration (Fullin and Reyneri 2011), and there is a gender divide in the insertion of migrants into the labour market (Vidal-Coso, Gil, and Domingo 2012). Other authors (Finotelli 2007) have cited southern Europe's migratory policies as a central reason why growing numbers of migrants are entering Spain. Unlike their northern and western European neighbours, countries in the south have a reduced capacity to control immigration and are more flexible in the management of irregular migrants, having implemented successive regularisation processes and other legalisation mechanisms.

Furthermore, Spain is an example of a destination that has become especially attractive to female migrants; since mid-1990s, and especially since the beginning of the 21st century, there has been a marked increase in the numbers of immigrant women arriving in the country to live and work. Like migration to other southern European countries, female migration to Spain has been a response to a specific demand for female labour caused by the internationalisation of domestic work (Reyneri 1996, 2004; King and Zontini 2000; Anthias and Lazaridis 2000; Solé 2003; Cachón 2009; Fullin and Reyneri 2011). The origins of this labour demand are related to Spain's weak welfare state, as well as to the spectacular transformation of women's roles during the final decades of the 20th century, as immigrant domestic maids began to participate in a form of replacement mobility that allows female nationals with rising levels of education to pursue their own careers (Lim 1997). The existence of this labour demand explains in part the high labour participation rates of immigrant women in Spain, and the fact that their first jobs after migration are often in housekeeping or elderly care. The individual characteristics of these migrants, such as their education or their previous labour experience, are less important in their initial integration into the labour market in Spain (Vidal-Coso 2009). In this sense, the domestic and family care sector is playing an important role in drawing independent female migrants to southern Europe (Bettio, Simonazzi and Villa 2006). 
Although female immigration plays an important role in Spain's labour market and elsewhere in southern Europe, and studies show that foreign-born women are highly concentrated in housework and care work (Bettio, Simonazzi, and Villa 2006; Barone and Mocetti 2011), research on the labour mobility experienced by immigrant women at the time of migration and during subsequent occupational transitions has been very limited. Until recently, the quantitative analysis of the occupational mobility of immigrants between their country of origin and their destination in southern Europe has been limited due to the lack of appropriate data. However, the necessary data became available in Spain with the publication of the results of the 2007 National Immigrant Survey (ENI). Studies based on this dataset have confirmed the assumption that female migrants in Spain are more prone to suffer downward mobility upon arrival in Spain than male migrants (Stanek and Veira 2009; Simón, Ramos, and Sanromá 2011). Studies that have conducted separate analyses for men and women have shown that migration itself is the biggest culprit in the decline in the occupational levels in both sexes, and that there is a strong pattern of females transitioning to domestic services after migrating to Spain, regardless of their national origin and previous job (Veira, Stanek, and Cachón 2011; Vono and Vidal-Coso 2012). The economic support of the spouse in the settlement process has been shown to contribute to both men's and women's upward labour mobility by easing the economic pressure they experience (Vono and Vidal-Coso 2012); this finding underlines the importance of networks to the success of household migration strategies (Massey et al. 2001). Despite its breadth, prior research has yet to explore either the role of domestic work in the labour market disadvantage of female migrants, or the prospects of foreign-born domestic workers to move into other labour market positions after a period of time.

Furthermore, prior investigations in Spain of the female labour market experience have generally adopted a qualitative perspective. Parella (2003) argued that although immigrant women have access to a reduced range of jobs, women's entry into the labour market should not be analysed from a static perspective, and that their labour careers should be differentiated by each woman's national origin, family characteristics, time in the country, and educational level. The research team "Colectivo Ioe" (2003) stressed the importance of domestic services as the most common entry portal into the Spanish labour market for immigrant women, regardless their skills or previous labour experience. However, these authors also identified some typical labour trajectories that could be considered upward mobility: e.g., from domestic services in private households to working for cleaning companies or the tourism sector. Oso (2003) also pointed out the importance of each woman's length of residence in Spain, her family characteristics, and her household migration strategy in explaining her labour position. In the first stage of the migratory process, a woman may accept work as a domestic because it is the easiest way to earn and save money, especially if she arrives in Spain 
without other family members. However, all of the previous studies have recognised that when immigrant women believe their stay in Spain to be permanent, their ambition is clearly directed to other labour positions: i.e., those occupied primarily by Spanishborn women.

\subsection{Research hypotheses}

We study the labour mobility of immigrant women around the time of migration, and their occupational trajectories throughout their careers in the country of destination. Our objective is to gain a better understanding of the role that domestic and cleaning occupations in private households play in the labour prospects of female immigrants in Spain. More concretely, we develop three different analyses on labour mobility.

Our first analytical objective is to highlight the role of employment in housework or family care work as the main explanation for the greater risk of downward labour status mobility among women than among men, even after controlling for sociodemographic characteristics. Using multinomial logistic regression analyses, we therefore focus first on the labour mobility (downward or upward versus lateral) of foreign-born workers around the time of migration: from the last job they have in the country of origin to the first job they get in Spain. We also compare the occupational movement of foreign-born women with that of foreign-born men. Our hypothesis is that even after controlling by individual characteristics, downward mobility versus lateral mobility is higher for women. Second, using descriptive analysis (mobility matrixes), we find that whereas foreign-born men are more evenly spread across the occupational scale in their first insertion into the Spanish labour market, cleaning and domestic work is the typical entry point of immigrant women into the Spanish labour market. Finally, we will consider, separately for men and women, the effects of the socio-demographic and migratory characteristics of immigrants in such movements. In line with human capital theory, we expect to find an improvement in labour market performance after migration to Spain among both male and female migrants with more education or higher skill levels, as measured by their educational attainment and previous occupational status. Moreover, we hypothesise that older migrants, who usually have more employment experience, will experience less occupational downgrading and more lateral mobility. Regarding the structural theoretical framework, we expect to find that EU-25 migrants and those from North America and Oceania will have greater relative opportunities to improve their occupational category or to maintain their job category after joining the Spanish labour market. By contrast, we expect to find that migrants from less developed regions will experience steeper declines in their labour status. Africans in particular are likely to experience discrimination, whereas Latin Americans 
are expected to experience lesser occupational penalties after migration, as they are linguistically and culturally closer to the native population. Moreover, in line with the social network approach, we hypothesise that the effect of having a social network on a migrant's labour market attainment at the destination will be shown to be ambiguous. On one hand, having a spouse already living in Spain prior to arrival can help the migrant avoid downward mobility, as she will have an increased ability to be selective about the types of jobs she takes, and will have less urgent economic requirements. However, a contrary effect is expected if the migrant has children at the time of migration. Moreover, given the segmentation dynamics in the labour market, informal networks may lead the migrant to take the most unskilled and informal jobs, and may thus increase the likelihood that she will experience a downward movement in her occupation status.

Second, we focus specifically on foreign-born women with the aim of identifying the socio-demographic factors which increase the likelihood that an immigrant woman's first job in Spain will be in cleaning or domestic work. Our expectations are that, regardless of the importance of the women's individual characteristics, the informality of the domestic sector and the role of migrant networks in recruitment for this sector are key elements that explain why the labour market status of immigrant women tends to be lower in the destination country than in the country of origin. Our hypotheses regarding the effects of an immigrant's national and educational origins, her age, and her family characteristics on her likelihood of entering the Spanish labour market as a domestic worker are in line with the above-mentioned hypotheses regarding the downward labour mobility of immigrant women after migration. However, we hypothesise that a Latin American woman will be more likely than a member of another group to enter the labour market as a domestic worker, due to the cultural and linguistic proximity of Latin American to Spanish society.

Third, we investigate the labour mobility of foreign-born women after their migration to Spain, from the first job they take after migration to the job they hold at the time of data collection. We then considers the importance of the assimilation process in Spain in the movement from the cleaning and domestic occupations (the entry portal to employment in Spain) to other labour market positions, after controlling for other socio-demographic, educational, and family characteristics. In line with Akresh (2006), we expect to find that more time spent in Spain will lead a migrant to have a better understanding of the labour market, greater institutional knowledge, and higher quality networks. Our hypothesis is therefore that taking a job in domestic services does not define a woman's long-term occupational trajectory, and that the likelihood that she will abandon domestic or care work increases with the amount of time she spends in Spain. Furthermore, we also expect to find positive trajectories among younger and more skilled immigrant women who at the time of data collection 
stated that they are able to speak Spanish or another co-official language, have a partner who is a native, have obtained or validated an educational diploma in Spain, or are residing legally in the country.

To assess the direction of labour mobility, we recognise that the structure of the labour market is unequal, and is ordered into differentiated labour positions. These positions are expressed as occupations, and these occupations may in turn be characterised by the economic and social rewards they provide (Blau and Duncan 1967; Hope 1972; Goldthorpe and Hope 1974; Parkin 1978; Goldthorpe 1980). Labour mobility is therefore determined by the opportunities an immigrant has to change her relative position in a predetermined structure of inequality. We view cleaning and domestic work as situated at the bottom of the female occupational structure, although some may argue that domestic maids share the same low status and salary as other workers within the secondary segment who are employed in elementary occupations in agriculture or industry, or in hotels or restaurants. However, the significant percentage of immigrant women in domestic services indicates that domestic and cleaning occupations in private households are a clear labour market gateway in Spain, the main starting point from which women can then move within the destination labour market. In fact, the informality and the role played by migrant networks in hiring for these jobs is evidence that most female immigrants use domestic work in private households as a way to obtain legal residence in Spain: once legal status is obtained, women move on towards other occupations (Escrivà 2000; Oso 2003). As a result, occupational transitions are expected in this context. Moreover, other characteristics of domestic work intensify its low status nature, including the private and isolated nature of this kind of job, and especially regulation of this work by the labour and social security legal regimes, which grant fewer rights to domestic maids than to other workers (Parella 2009).

\section{Data and methods}

\subsection{The 2007 National Immigrant Survey (ENI-2007)}

This investigation uses the 2007 National Immigrant Survey (Encuesta Nacional de Inmigrantes, ENI-2007) conducted by the Spanish National Institute of Statistics (Instituto Nacional de Estadística, INE), with a sample size of 15,465 immigrants: 6,964 men and 8,501 women. This survey was designed to focus exclusively on the immigrant population in Spain in order to study their socioeconomic, household, and demographic characteristics. The respondents were drawn from the entire immigrant population in Spain aged 16 years or older. The ENI defines an immigrant as a foreign- 
born resident of Spain (regardless of his or her nationality) who had resided in Spain for at least a year, or who had the intention to remain in Spain for at least a year. Individuals who were born abroad with Spanish nationality and who moved to Spain before the age of two were not considered immigrants by the ENI, and were not eligible to be interviewed (Reher and Requena 2009). The ENI's sampling frame was based on the nationwide Padrón Municipal de Habitantes (Spanish Municipal Register), and the data collection took place between November 2006 and February 2007, with the week prior to the interview used as a reference period. Reher et al. (2008) noted that this new dataset is the only representative data source for all migrants in Spain, and that it includes retrospective information about each respondent's life course and migration process from the moment the decision to migrate was made to the person's arrival and subsequent settlement in Spain. However, as Simón, Ramos, and Sanromà (2011) pointed out, although the ENI includes retrospective information on immigrants, it is composed of single cross-sectional data. Nevertheless, in the absence of prospective longitudinal data for Spain regarding migrants' labour characteristics the ENI is the best data source for our analytical purposes.

The ENI-2007 captured each respondent's labour market characteristics at three crucial moments: immediately prior to migration (the last job held in in the country of origin before migration), immediately following entry (the first job held in Spain), and at the time of data collection (between 2006 and 2007). For individuals who held at least one job prior to migration and at least one job since arriving in Spain, we can analyse their occupational mobility from the country of origin to the first job in Spain. For those who have had more than one job since arrival and were working at the time of data collection, we can also analyse their occupational mobility (downward, upward, or none). Finally, occupational immobility (lateral) is analysed for those workers who have held only one job since their initial entrance into the Spanish labour market.

However, the ENI-2007 data has two important deficiencies. First, since the survey only includes immigrants, it is not possible to compare the patterns of the foreign-born population with those of the native-born population on the basis of the ENI data alone. Second, the ENI contains only an approximation of individual labour trajectories, and is not exhaustive. Moreover, although the ENI elicited information about the total number of employment contracts the respondent signed since arriving in Spain, more than $10 \%$ of the respondents who stated that they had only ever held one job in Spain also reported having signed various employment contracts in Spain. We believe that this reflects the fact that some individuals were working for different employers at the same time, as is typical of domestic workers. In light of the prevalence of the practice of parallel employment in domestic and care services, we chose to exclude this information from our analysis. 


\subsection{Sample description and explanatory variables}

We applied certain restrictions to our sample. First, we limited our sample to immigrants who arrived in Spain from 1990 onwards in order to focus on those immigrants who arrived in the new era of economic migration. ${ }^{3}$ Second, our sample only included those respondents who were working or searching for a job prior to migration, and who had ever worked in Spain. Based on these criteria we selected 3,778 men and 3,469 women for our analysis out of the 6,964 men and 8,501 immigrant women interviewed in the ENI (see Table 1). Of these individuals we selected, 3,657 men and 3,310 women had provided information about their last occupation prior to their migration to Spain. Therefore, these are the immigrants we included in our analysis of labour mobility at migration. Third, we restricted the regression analysis of mobility upon arrival to migrants who had arrived in Spain between the ages of 20 and 64 , and who had obtained their highest educational degree abroad ${ }^{4}$. Fourth, the sample was restricted to 2,699 women who were employed at the time of data collection for the second analysis of labour mobility during residence in Spain. The multivariate model of labour mobility from the initial entry into the Spanish labour market as a domestic worker was again limited to respondents aged 20-64 at the time of migration, but this last model also included immigrants who had finished their schooling in the host country.

\footnotetext{
${ }^{3}$ Cachón (2002) explained that this era started during the second half of the 1980s in Spain. We justify the decision to restrict the sample to this era to avoid potential biases associated with using cross-sectional data for the analysis of the labour market outcomes of migrants. Chiswick, Lee, and Miller (2005) argued that bias could happen if there are changes over time in the quality of immigrant cohorts, selectivity in return migration or third-country migration, changes in the labour market, or different economic cycles. In order to minimise this potential bias, we restricted our sample to the new era of labour migration in Spain, when immigrants arrived during a phase of growing immigrant labour demand. Furthermore, the data were collected before the current economic crisis, when return migration was a minimal phenomenon.

${ }^{4}$ Although the number of immigrants who finished their schooling in the host country is relative low (146 men and 173 women, respectively, the $4 \%$ and $5.5 \%$ of our selected male and female samples), for the labour mobility analysis at migration, we limited our sample to those who completed their education before migrating to Spain, as returns to human capital may vary depending on where this education was obtained; i.e., in Spain or abroad.
} 
Vidal-Coso \& Miret-Gamundi: The labour trajectories of immigrant women in Spain

Table 1: Sample sizes and distribution of immigrants' characteristics at arrival

\begin{tabular}{|c|c|c|c|c|c|c|}
\hline \multirow{2}{*}{ Variable } & \multicolumn{2}{|c|}{ Men } & \multicolumn{2}{|c|}{ Women } & \multicolumn{2}{|c|}{ Total } \\
\hline & $\mathbf{N}$ & $\%$ & $\mathrm{~N}$ & $\%$ & $\mathbf{N}$ & $\%$ \\
\hline Total sample & 3,778 & $52.1 \%$ & 3,469 & $47.9 \%$ & 7,247 & $100 \%$ \\
\hline \multicolumn{7}{|l|}{ Area of Birthplace } \\
\hline Latin America & 1,560 & $41.3 \%$ & 2,000 & $57.7 \%$ & 3,560 & $49.1 \%$ \\
\hline EU-25 & 474 & $12.5 \%$ & 440 & $12.7 \%$ & 914 & $12.6 \%$ \\
\hline Rest of Europe & 780 & $20.6 \%$ & 776 & $22.4 \%$ & 1,556 & $21.5 \%$ \\
\hline Africa & 821 & $21.7 \%$ & 183 & $5.3 \%$ & 1,004 & $13.9 \%$ \\
\hline North America and Oceania & 22 & $0.6 \%$ & 16 & $0.5 \%$ & 38 & $0.5 \%$ \\
\hline Asia & 121 & $3.2 \%$ & 54 & $1.6 \%$ & 175 & $2.4 \%$ \\
\hline Total & 3,778 & $100 \%$ & 3,469 & $100 \%$ & 7,247 & $100 \%$ \\
\hline \multicolumn{7}{|l|}{ Age on arrival } \\
\hline Less than 16 & 7 & $0.2 \%$ & 6 & $0.2 \%$ & 13 & $0.2 \%$ \\
\hline $16-19$ & 148 & $3.9 \%$ & 124 & $3.6 \%$ & 272 & $3.8 \%$ \\
\hline $20-24$ & 769 & $20.4 \%$ & 726 & $21.0 \%$ & 1,495 & $20.7 \%$ \\
\hline $25-29$ & 1,050 & $27.9 \%$ & 900 & $26.0 \%$ & 1,950 & $27.0 \%$ \\
\hline $30-34$ & 770 & $20.4 \%$ & 665 & $19.2 \%$ & 1,435 & $19.9 \%$ \\
\hline $35-39$ & 453 & $12.0 \%$ & 438 & $12.7 \%$ & 891 & $12.3 \%$ \\
\hline $40-44$ & 284 & $7.5 \%$ & 264 & $7.6 \%$ & 548 & $7.6 \%$ \\
\hline $45-49$ & 155 & $4.1 \%$ & 194 & $5.6 \%$ & 349 & $4.8 \%$ \\
\hline $50-54$ & 77 & $2.0 \%$ & 96 & $2.8 \%$ & 173 & $2.4 \%$ \\
\hline $55-59$ & 37 & $1.0 \%$ & 33 & $1.0 \%$ & 70 & $1.0 \%$ \\
\hline $60-64$ & 13 & $0.3 \%$ & 14 & $0.4 \%$ & 27 & $0.4 \%$ \\
\hline 65 or more & 3 & $0.1 \%$ & 2 & $0.1 \%$ & 5 & $0.1 \%$ \\
\hline Total & 3,766 & $100 \%$ & 3,462 & $100 \%$ & 7,228 & $100 \%$ \\
\hline \multicolumn{7}{|l|}{ Educational level } \\
\hline Less than compulsory & 470 & $12.4 \%$ & 247 & $7.1 \%$ & 717 & $9.9 \%$ \\
\hline Primary or compulsory & 631 & $16.7 \%$ & 455 & $13.1 \%$ & 1,086 & $15.0 \%$ \\
\hline Secondary & 2,028 & $53.7 \%$ & 1,911 & $55.1 \%$ & 3,939 & $54.4 \%$ \\
\hline University & 649 & $17.2 \%$ & 856 & $24.7 \%$ & 1,505 & $20.8 \%$ \\
\hline Total & 3,778 & $100 \%$ & 3,469 & $100 \%$ & 7,247 & $100 \%$ \\
\hline \multicolumn{7}{|l|}{ Partnership on arrival } \\
\hline Partner already in Spain & 137 & $3.6 \%$ & 311 & $9.0 \%$ & 448 & $6.2 \%$ \\
\hline No partner & 1,769 & $46.8 \%$ & 1,879 & $54.2 \%$ & 3,648 & $50.3 \%$ \\
\hline Partner other circumstances & 1,872 & $49.6 \%$ & 1,279 & $36.9 \%$ & 3,151 & $43.5 \%$ \\
\hline Total & 3,778 & $100 \%$ & 3,469 & $100 \%$ & 7,247 & $100 \%$ \\
\hline \multicolumn{7}{|l|}{ Children on migration } \\
\hline No children & 2,115 & $56.0 \%$ & 1,601 & $46.2 \%$ & 3,716 & $51.3 \%$ \\
\hline Children & 1,663 & $44.0 \%$ & 1,868 & $53.8 \%$ & 3,531 & $48.7 \%$ \\
\hline Total & 3,778 & $100.0 \%$ & 3,469 & $100.0 \%$ & 7,247 & $100.0 \%$ \\
\hline \multicolumn{7}{|l|}{ Method of seeking the first job } \\
\hline Formal methods & 1,219 & $32.3 \%$ & 1,219 & $35.1 \%$ & 2,438 & $33.6 \%$ \\
\hline Family and friends & 2,559 & $67.7 \%$ & 2,250 & $64.9 \%$ & 4,809 & $66.4 \%$ \\
\hline Total & 3,778 & $100 \%$ & 3,469 & $100 \%$ & 7,247 & $100 \%$ \\
\hline
\end{tabular}


Table 1: (Continued)

\begin{tabular}{|c|c|c|c|c|c|c|}
\hline \multirow{2}{*}{ Variable } & \multicolumn{2}{|c|}{ Men } & \multicolumn{2}{|c|}{ Women } & \multicolumn{2}{|c|}{ Total } \\
\hline & $\mathbf{N}$ & $\%$ & $\mathbf{N}$ & $\%$ & $\mathbf{N}$ & $\%$ \\
\hline \multicolumn{7}{|l|}{ Occupation in country of origin } \\
\hline Managerial Occupation & 244 & $6.7 \%$ & 173 & $5.2 \%$ & 417 & $6.0 \%$ \\
\hline Technical and Professional occupation & 601 & $16.4 \%$ & 896 & $27.1 \%$ & 1,497 & $21.5 \%$ \\
\hline Skilled occupation & 1,519 & $41.5 \%$ & 461 & $13.9 \%$ & 1,980 & $28.4 \%$ \\
\hline Administrative and Secretarial occupation & 157 & $4.3 \%$ & 404 & $12.2 \%$ & 561 & $8.1 \%$ \\
\hline Services occupation & 537 & $14.7 \%$ & 948 & $28.6 \%$ & 1,485 & $21.3 \%$ \\
\hline Elementary occupation: Other & 209 & $5.7 \%$ & 176 & $5.3 \%$ & 385 & $5.5 \%$ \\
\hline Elementary occupation: Cleaning and domestic services & 4 & $0.1 \%$ & 187 & $5.6 \%$ & 191 & $2.7 \%$ \\
\hline Elementary occupation: Construction & 165 & $4.5 \%$ & 2 & $0.1 \%$ & 167 & $2.4 \%$ \\
\hline Elementary occupation: Agriculture and Farming & 221 & $6.0 \%$ & 63 & $1.9 \%$ & 284 & $4.1 \%$ \\
\hline Total & 3,657 & $100 \%$ & 3,310 & $100 \%$ & 6,967 & $100 \%$ \\
\hline
\end{tabular}

Data source: National Immigrant Survey 2007 (ENI-2007).

In our analysis of the occupational mobility of migrants in Spain, we included several socio-demographic explanatory variables: sex, age, region of origin (birth), family characteristics, and educational level. Immigrants were grouped by region of origin: Latin America, the EU-25 $5^{5}$ the rest of Europe, Africa, Asia, and a single category for both North America and Oceania. As very few women from Asia or North America and Oceania were interviewed, the findings for these groups were not always statistically significant. In addition, other variables related to the migration experience were included: the duration of stay since migration, whether previous migrant networks (family and friends) contributed to the initial post-migration job search, whether the migrant's level of education was obtained or validated in Spain or abroad, the migrant's language proficiency, and the migrant's legal status. The covariates used representative information relating to the period of interest (at the time arrival or at the moment of data collection). In other words, the variables were time-constant within each part of the analysis. However, other information was limited to the time of the survey: e.g., the migrant's educational attainment and whether this education was completed or validated once in Spain, the migrant's ability to speak Spanish or another co-official language, and the migrant's legal residency status. While we assume that a respondent's educational level at the time of the survey generally coincides with her educational level at the time of migration, especially if she finished her training abroad or migrated after the age of 25; the rest of these characteristics may have changed from the time of arrival to the time they were measured by the survey, as they may reflect the

\footnotetext{
${ }^{5}$ In this paper, Bulgarian and Romanian women are considered non-communitarian (non-EU 25) immigrants since the incorporation of their countries into the European Union did not occur until 2007. Moreover, the labour characteristics and the volume of immigration from these countries made it necessary to differentiate these women from EU-25 immigrants.
} 
assimilation process in Spain. We therefore include these characteristics only in the third analysis on mobility since arrival.

\subsection{Methods of analysis: The labour mobility matrix and logistic regression}

We used three quantitative methods: the mobility matrix, multinomial logistic regression, and binary logistic regression. The first method used is the labour mobility matrix, $\mathrm{N}=\left(\mathrm{n}_{\mathrm{ij}}\right)$, presented in Tables 3 and 6:

$\mathrm{N}=$ Total immigrant men/women.

$\mathrm{n}_{\mathrm{i}}=$ Total immigrant men/women in the category of origin given (i), time of origin $\left(\mathrm{t}_{0}\right)$ : Row marginal.

$n_{j}=$ Total immigrant men/women in the category of destination given (j), time of destination $\left(\mathrm{t}_{1}\right)$ : Column marginal.

The cells on the diagonal (upper left to bottom right) represent the immigrant women who did not change their occupational category from the time of origin $\left(\mathrm{t}_{0}\right)$ to the time of destination $\left(t_{1}\right)$, while the other cells represent the women who experienced mobility. The occupational categories follow a hierarchical order: from low-paid, unstable positions with poor working conditions and little chance of advancement at the bottom of the scale; to the most stable, well-paid, and prestigious positions at the top. As a result, the cells above the diagonal represent the percentages of women who experienced downward occupational mobility between $t_{0}$ and $t_{1}$, and the cells below represent the women who experienced upward mobility. This matrix is named the total relative distribution matrix (1) (Cachón 1989):

$$
\begin{gathered}
P_{i j}=n_{i j} / N \\
\sum P_{i j} \cdot 100=100 \%
\end{gathered}
$$

In this matrix, we consider the proportions of immigrant women who were in category $i$ at the time of origin $\left(\mathrm{t}_{0}\right)$ and in category $j$ at the time of destination $\left(\mathrm{t}_{1}\right)$, as well as the adjusted standardised residuals. If the residual has a high value (higher than 1.96 or lower than -1.96), it is statistically significant and indicates dependency between the category of origin and of destination.

The second analytical method of labour mobility is the construction of multivariate models using multinomial logistic regression (2) (Tables 2 and 4). This method is used to investigate the association between our explanatory variables and the direction of 
labour mobility (downward and upward versus lateral), and between the occupation individuals held prior to migration and the first occupation in Spain:

$$
\log \frac{\pi_{i M}}{\pi_{i L}}=\alpha+\beta_{1} x_{i}+\beta_{2} X_{i}+\ldots+\beta_{n} x_{i}
$$

Where $\pi_{\mathrm{im}}$ is the probability of an immigrant's occupational mobility (upward or downward) and $\pi_{\mathrm{iL}}$ is the probability of an immigrant's occupational lateral mobility.

The third method we use is binary logistic regression (3) (Tables 5 and 7). First, we calculate the probability that domestic work will be the first occupation of migrant women in Spain. Second, we calculate the likelihood of abandoning domestic work for other occupations:

$$
\log (y / y-1)=\alpha+\beta_{1} x_{1+} \beta_{2} x_{2+} \cdots+\beta_{n} x_{n}
$$

where $y$ is the probability that the event of interest occurs, and $1-y$ is the probability of the event's non-occurrence. In both equations, $\alpha$ is the constant and $\beta_{i}$ are the regression coefficients of the explanatory variables $\mathrm{x}_{i}$. Beta coefficients ( $ß$ ) show the relative importance of the independent variables in the determination of the outcome variable. In the case of models like those constructed here, the estimated probability of $\pi_{\mathrm{iM}}=1$ or $\mathrm{Y}=1$ is interpreted as being the adjusted likelihood of the whole effect of all covariates in the model. As we found no interaction effects between our explanatory variables in any of the multivariable analyses, (results available upon request), we consider only their net effects here.

\section{Results}

\subsection{The occupational mobility that the migratory process entails}

Table 2 depicts the multinomial logistic regression model created to analyse the relative risk that an immigrant will experience downward or upward occupational mobility versus immobility (or lateral occupational movement) from her last job in the country of origin to her first job in Spain, after controlling by the influence of explanatory variables. The categories of our dependent variable are mutually exclusive and exhaustive, and the baseline category $(y=0)$ is lateral mobility, which occurs when the level of the immigrant's first job in Spain is equal to that of her occupation prior to migration. Downward mobility occurs $(y=1)$ when the respondent's occupation level in 
her first job in Spain is of lower status than her last job in the country of origin. Finally, upward mobility occurs $(y=2)$ when the immigrant's first job held in Spain represents a better labour position on the occupational scale.

The main conclusion we can draw from these models is that, compared to men, women were three times as likely (3.01) to experience downward movement in their occupational status at the time of migration to Spain, even after controlling for sociodemographic characteristics; and that women were half as likely as men to experience upward mobility. Therefore, our first hypothesis was clearly confirmed: i.e., women were disadvantaged as they entered the labour market after migrating to Spain. This outcome is in line with structural or segmentation theory, which states that the more heavily represented women are in less prestigious jobs, the greater the difficulties they face in improving their occupational position.

Based on these results, we can observe that human capital affects the three mobility options in an ambiguous manner. On the one hand, in line with human capital theory, the coefficients by educational levels indicate that the higher an immigrant's educational attainment, the greater the likelihood that she was able to secure a more prestigious position once in Spain. Meanwhile, foreign-born workers with lower educational levels were less likely to move down than to move laterally on the occupational scale after migration-although they were also less likely to move up the scale. This finding reflects the types of jobs lower-skilled immigrants tend to have access to in both the country of origin and the country of destination. Finally, we should highlight the significantly higher risk of a downward move in occupational status among immigrants with a secondary education only relative to those with a university education.

On the other hand, contrary to human capital theory, previous labour experience did not appear to prevent a loss of labour status after migration: the higher the category of the job the migrant held in the country of origin, the more likely it was that she experienced downward mobility, and the less likely it was that she moved into a higher labour category. It is interesting to note that the migrants who worked in administrative and secretarial occupations in their country of origin were clearly the most mobile once in Spain. However, this mobility was not always positive for these women, as they had the highest relative odds of experiencing both downward and upward mobility. Furthermore, the ceiling and floor effects may explain why the immigrants who were employed in low-status jobs in the country of origin were more likely to have found a better job once in Spain, as the relative coefficients for upward over lateral mobility suggest. However, in line with human capital theory, these results may reflect the difficulties foreign-born workers face in transferring and validating their pre-migration labour market experience during the process of adjustment to the host country. 
Moreover, our expectation that older migrants would move down the occupational scale to a lesser extent due to their longer employment experience was only partially supported by the models, as only the individuals who arrived when they were 55-64 years old had a significantly lower risk of being downgraded.

The coefficients for birthplace were in line with the structural or segmentation hypothesis of Heath and Cheung (2007) with regard to the "ethnic penalty": i.e., that immigrants from particular countries of origin are likely to experience greater obstacles than others when entering the labour market in Spain, regardless of their sociodemographic and human capital characteristics. The results clearly show that immigrants from the European Union, and, to a lesser extent, those from North America and Oceania, experienced the most success in moving into the host labour market, as they were overrepresented in higher quality jobs that require high levels of education (Reher and Requena 2009). Their relative chances of downward mobility were lower, and their coefficients for improving their occupational status were disproportionally higher than those of others. Our interpretation of this finding is in line with Bernardi, Garrido, and Miyar (2011), who observed that the higher levels of occupational and educational success among EU-15 and OECD immigrants may be attributable to Spanish migration policies and EU regulations regarding the free movement of the labour force across Europe. Thus, the fact that these immigrants were more likely than other immigrants to have had valid work and residency permits explains why they were more likely to have been employed in a skilled occupation. Moreover, these immigrants did not face bureaucratic impediments to the formal recognition of the education they obtained abroad. Latin Americans (the group of reference) and non-communitarian Europeans, followed by Asians, were somewhat more likely than EU-15 and OECD immigrants to have faced the ethnic penalty. However, Africans were penalised the most heavily post-migration, as they were the most prone to suffer downward occupational mobility in their initial insertion into the Spanish labour market.

Our analysis of the impact of family arrangements revealed that, contrary to our initial hypothesis, partnership status at the time of migration was not a significant factor in the direction of labour mobility (down or up). Having a partner who was living in Spain before the respondent's own migration was not found to be significant, despite our assumption that having a spouse who was already settled in Spain would have lessened the likelihood that the migrant would experience downward mobility, as this situation should have allowed her to be more selective in her job search. However, other findings reinforced our hypothesis: immigrants with children at the time of migration had higher odds (1.21) of losing their occupational status after migration relative to those without children, the reference category. A possible explanation for the major decline in labour market attainment among immigrants with children is that these individuals were less able to be selective about the level at which they entered the 
labour market because the economic demands on them were more urgent. However, having children did not affect upward mobility to the same extent: while immigrants with children found it more difficult than those without children to move up the occupational scale, with relative odds of 0.83 ; this effect was not statistically significant.

Finally, the results regarding the role of family members and friends in the migrants' job search are in line with social capital theory. The coefficients suggest that the immigrants who found their first job in Spain via a migrant network were more likely to have experienced downward mobility (1.94) than those who found their first job through more formal methods (e.g., contacting public or private employment offices or sending applications to potential employers). However, the influence of this variable on upward mobility versus immobility was not significant.

Table 2: $\quad$ Likelihood of labour mobility (downward and upward vs. lateral): coefficients of the multinomial logistic regression model. Pooled models for immigrant men and women

\begin{tabular}{|c|c|c|c|}
\hline Variables & Freq. & $\begin{array}{l}\text { Downward mobility } \\
\text { vs. } \\
\text { Lateral mobility } \\
\operatorname{Exp}(ß)\end{array}$ & $\begin{array}{l}\text { Upward mobility } \\
\text { vs. } \\
\text { Lateral mobility } \\
\operatorname{Exp(ß)}\end{array}$ \\
\hline \multicolumn{4}{|l|}{ Sex } \\
\hline Men & 3,367 & 1 & 1 \\
\hline Women & 3,019 & $3.01^{\star \star \star}$ & $0.44^{\star \star \star}$ \\
\hline \multicolumn{4}{|l|}{ Area of Birthplace } \\
\hline Latin America & 3,173 & 1 & 1 \\
\hline EU-25 & 821 & $0.24^{\star \star \star}$ & $1.62^{\star \star *}$ \\
\hline Rest of Europe & 1,378 & $0.96^{*}$ & $0.71^{\text {ns. }}$ \\
\hline Africa & 830 & $2.06^{\star \star \star}$ & $0.68^{\text {ns. }}$ \\
\hline North America and Oceania & 33 & $0.36^{\star \star \star}$ & $3.32^{\text {ns. }}$ \\
\hline Asia & 151 & $1.10^{\mathrm{ns}}$ & $0.49^{\text {ns. }}$ \\
\hline \multicolumn{4}{|c|}{ Socio-demographic characteristics } \\
\hline \multicolumn{4}{|c|}{ Age on arrival } \\
\hline 20-34 & 4,436 & 1 & 1 \\
\hline $35-44$ & 1,359 & $0.81^{\text {ns. }}$ & $0.78^{\text {ns. }}$ \\
\hline $45-54$ & 499 & $0.89^{\text {ns. }}$ & $1.18^{\text {ns. }}$ \\
\hline $55-64$ & 92 & $0.62^{\star *}$ & $1.10^{\text {ns. }}$ \\
\hline
\end{tabular}


Table 2: (Continued)

\begin{tabular}{|c|c|c|c|}
\hline Variables & Freq. & $\begin{array}{c}\text { Downward mobility } \\
\text { vs. } \\
\text { Lateral mobility } \\
\operatorname{Exp}(ß)\end{array}$ & $\begin{array}{l}\text { Upward mobility } \\
\text { vs. } \\
\text { Lateral mobility } \\
\operatorname{Exp(ß)}\end{array}$ \\
\hline \multicolumn{4}{|l|}{ Educational Level } \\
\hline Primary or lower & 1,573 & $0.83^{\star \star \star}$ & $0.39 * \star \star$ \\
\hline Secondary & 3,477 & $1.41^{\star * *}$ & $0.74^{\star \star \star}$ \\
\hline University & 1,336 & 1 & 1 \\
\hline \multicolumn{4}{|l|}{ Family characteristics } \\
\hline \multicolumn{4}{|l|}{ Partnership on arrival } \\
\hline Partner already in Spain & 399 & 1 & 1 \\
\hline No partner & 3,081 & $0.71^{\mathrm{ns} .}$ & $0.92^{\mathrm{ns} .}$ \\
\hline Partner other circumstances & 2,906 & $0.66^{\mathrm{ns} .}$ & $1.23^{\mathrm{ns} .}$ \\
\hline \multicolumn{4}{|l|}{ Children on migration } \\
\hline No children & 3,110 & 1 & 1 \\
\hline Children & 3,276 & $1.21^{* * *}$ & $0.83^{\mathrm{ns} .}$ \\
\hline \multicolumn{4}{|l|}{ Role of social network } \\
\hline \multicolumn{4}{|l|}{ Method of seeking the first job } \\
\hline Formal methods & 2,122 & 1 & 1 \\
\hline Family and friends & 4,264 & $1.94^{\star * *}$ & 1.05 \\
\hline \multicolumn{4}{|l|}{ Occupation in country of origin } \\
\hline Managerial occupation & 393 & $6.87^{* \star *}$ & 0.00 \\
\hline Technical and Professional occupation & 1,346 & $3.47^{* * *}$ & $0.07^{\star *}$ \\
\hline Skilled occupation & 1,844 & $1.06^{*}$ & $0.06^{\star \star *}$ \\
\hline Administrative and Secretarial occupation & 517 & $6.32^{* * *}$ & $2.96^{\star \star *}$ \\
\hline Services occupation & 1,356 & 1 & 1 \\
\hline Elementary occupation & 930 & $0.00^{\text {ns. }}$ & $0.65^{\star \star *}$ \\
\hline \multicolumn{4}{|l|}{ Dependent variable: Labour mobility } \\
\hline Lateral (baseline category) & 2,324 & & \\
\hline Downward & 3,394 & & \\
\hline \multirow[t]{3}{*}{ Upward } & 668 & & \\
\hline & \multicolumn{2}{|r|}{-2 log likehood } & 4,103 \\
\hline & \multicolumn{2}{|r|}{ Chi-Square } & $3,374^{\star * \star}$ \\
\hline
\end{tabular}

Statistic significance = "ns" non significant; *: $p<0,10 ; * \star p<0,05 ; * \star *: p<0,01$.

Table 3 shows the total relative distribution matrix of the last occupation held by immigrant men and women in their country of origin, and their initial occupation upon arrival in Spain. It is evident that while there was a relationship between the occupations at origin and at destination (residuals of the cells in the diagonal) among 
both men and women, there was also a significant degree of downward occupational mobility. In line with the results of Anguiano (2001), our findings indicate that regardless of an immigrant's previous labour market experience, his or her initial entry into the labour market in Spain was most likely to have been in the secondary segment. However, the mobility tables show that there were large differences between male and female migrants in terms of occupational change at migration. Concretely, although both men and women tended to hold less skilled first jobs, the percentage of women in these positions was higher than the percentage of men: $81 \%$ of immigrant women, but just $52.8 \%$ of immigrant men, had their first job in the service occupations (hotels and restaurants, personal services, sales and customer services), the elementary occupations, or cleaning and domestic services. Furthermore, the mobility tables show that a portion of this overrepresentation of immigrants at the bottom of the occupational scale is attributable to a downward move post-migration. This trend was also more obvious among women than men: $41.5 \%$ of women and $31.0 \%$ of men had worked in these kinds of jobs before migration.

Finally, the results also confirm the gender segmentation of the immigrant labour force. The female occupational distributions pre- and post-migration demonstrate that cleaning and domestic services were the main entry portal into the Spanish labour market for immigrant women, independent of their previous labour experience. This occupational category increases from 5.6\% (employed women prior to migration) to $41.6 \%$ (first job of women post-migration). By contrast, foreign-born men were more equally distributed along the occupational scale after migrating. Furthermore, although high percentages of foreign-born men had their first job in service occupations (12.1\%) or in elementary occupations in agriculture (19.9\%) or construction (11.9\%), 33.8\% of men had their first job following arrival in a skilled manual occupation. In conclusion, women were significantly more likely than men to be concentrated and overrepresented in the lowest positions in the labour market after migrating to Spain.

In Table 4, we consider, separately for men and women, the roles played by sociodemographic characteristics, human capital, family arrangements, and migrant networks on the immigrants' occupational mobility (or lack thereof) from their last job in the country of origin to their first job in Spain. In general terms, while the results for men only (Table 4) coincide with the overall model (Table 2), the results for women only do not (Table 4). We believe this is a consequence of the fact that a larger share of women than men entered the Spanish labour market as a domestic or cleaning worker, as shown in Table 3. 
Table 3a: Total relative matrix of the previous occupation in country of origin and first occupation in Spain. Immigrant men who arrived from 1990 to 2007 and were aged 16-64 at arrival.

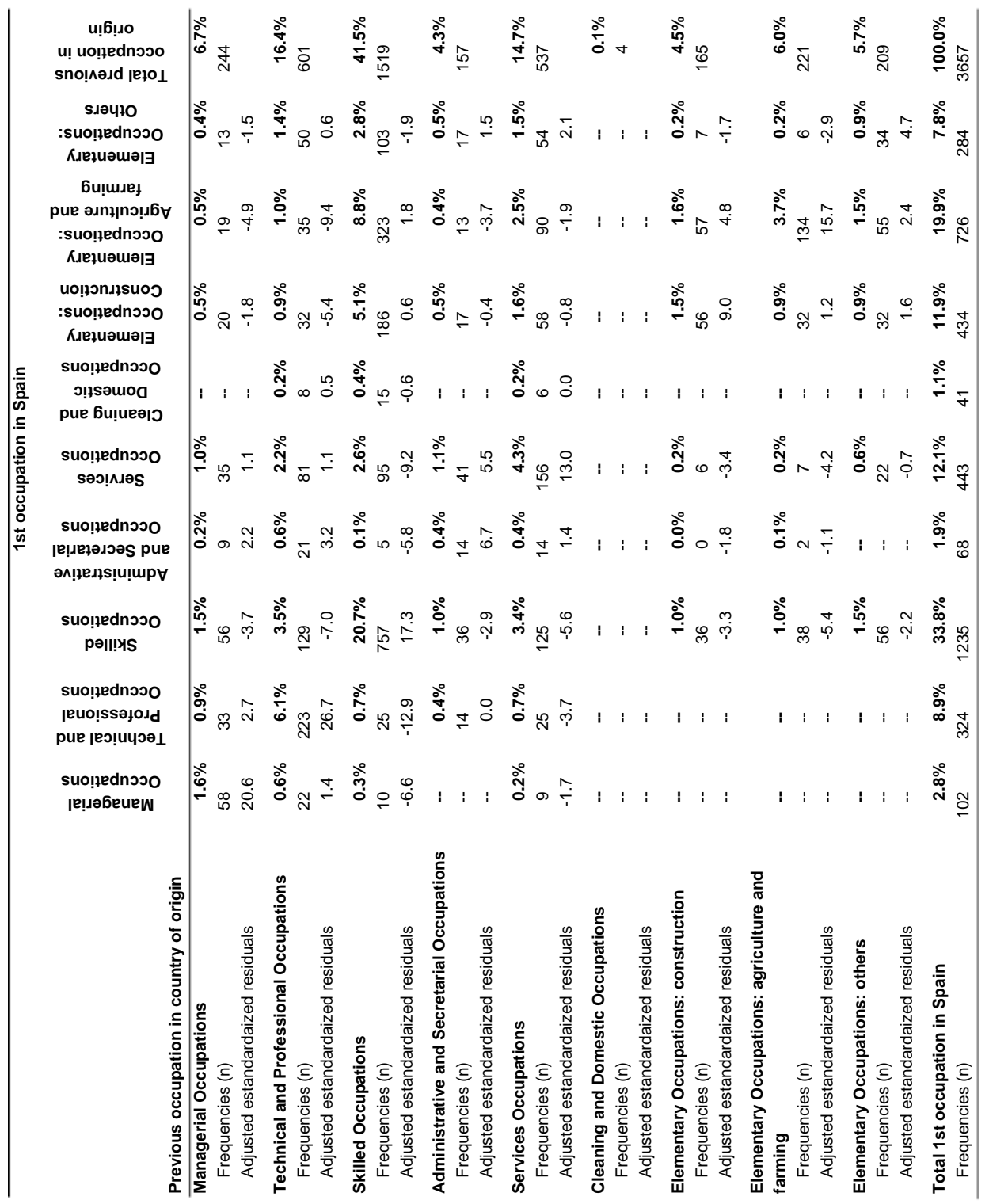


Table 3b: Total relative matrix of the previous occupation in country of origin and first occupation in Spain. Immigrant women who arrived from 1990 to 2007 and aged 16-64 at arrival

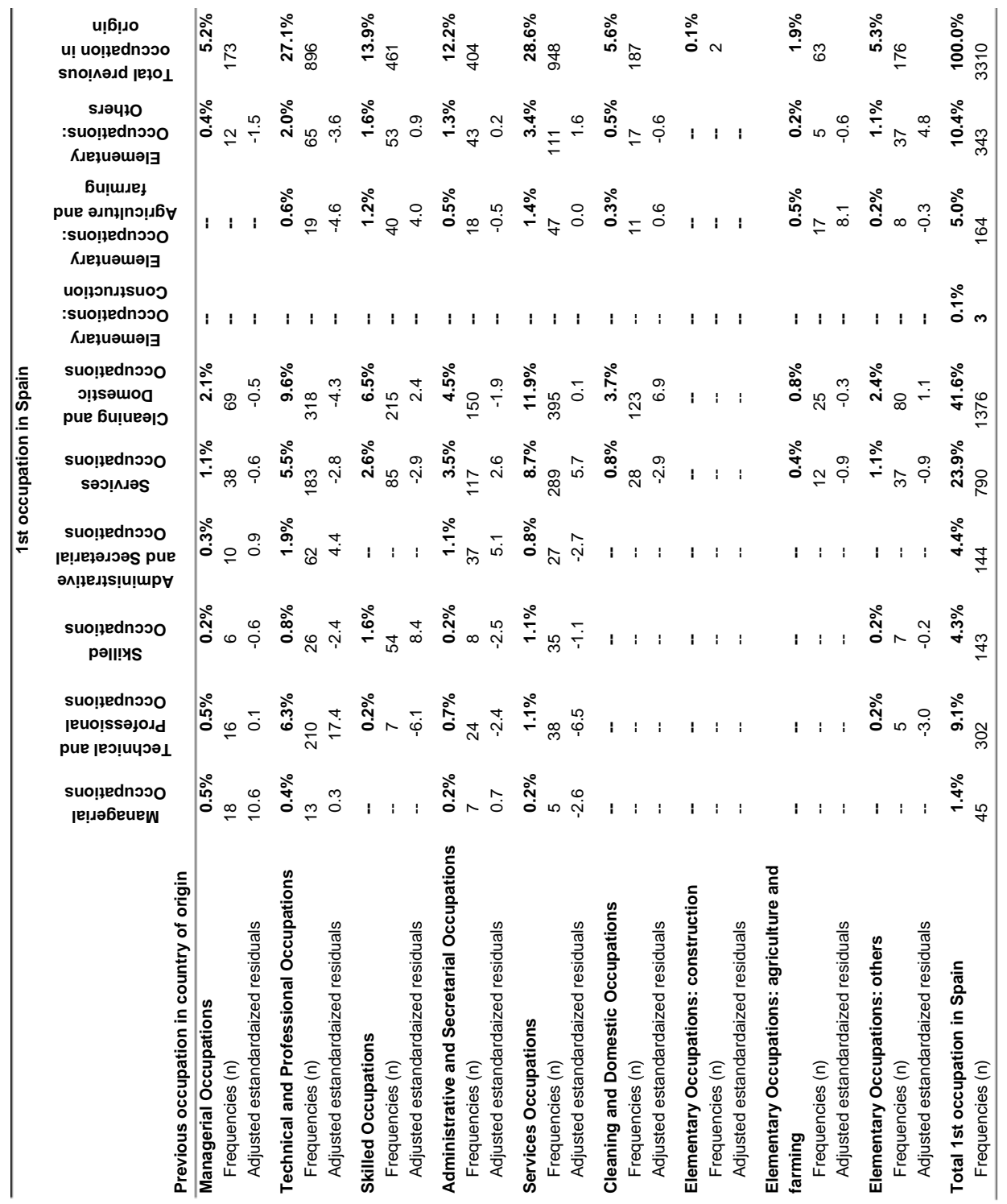


The coefficients for birthplace indicate that women from the EU-25 and Asia were the groups with the lowest probability of experiencing downward labour mobility compared to the reference category, although the differences between Asian and Latin American women were not significant. They were followed by women from Africa and North America and Oceania, but the differences between these groups and the women from Latin America were not significant. Women from non-EU Europe had the highest risk of moving down the occupational scale. When we analysed the characteristics associated with upward movement, we found that Latin American, African, and Asian women faced the greatest difficulties in improving their occupational status after migration to Spain, while women from the EU-25 were the most likely to improve their occupational status. However, women from non-EU Europe had slightly higher chances of moving up the occupational scale at migration than the reference group.

Furthermore, we observed that, while neither age nor marital status at arrival were significant factors in women's labour market mobility, having children doubled a woman's risk of experiencing downward mobility in her occupational status. Finally, the results were clear regarding the role played by the family and friends of foreignborn women in the job search process: a woman had a higher risk of downward mobility if her first job in Spain was obtained through migrant networks. Our interpretation of this finding is that it reflects the informality of the domestic and care sector.

In Table 3, we can see that immigrant women who entered the Spanish labour market as a domestic or cleaning worker were more likely than others to have experienced a downward occupational trajectory after the initial migration period. This finding is in line with previous empirical evidence that foreign-born women are concentrated in housework and care work in southern Europe. We now take the analysis one step further by investigating which individual characteristics are associated with this specific labour market path. In Table 5, the results of the binary logistic regression model show that women from Latin America were the most likely to enter the Spanish labour market as domestic workers, followed by women born in non-EU-25 Europe. Thus, the language proficiency and cultural proximity to Spanish society of Latin American women did not prevent them from being employed in domestic services. Instead, it appears that Spanish families prefer to hire these women instead of migrants from other origins precisely due to their cultural and language proximity. 
Vidal-Coso \& Miret-Gamundi: The labour trajectories of immigrant women in Spain

Table 4: Likelihood of labour mobility (downward and upward vs. lateral): coefficients of the multinomial logistic regression models. Immigrant men and women.

\begin{tabular}{|c|c|c|c|c|c|c|}
\hline & \multicolumn{3}{|c|}{ Men } & \multicolumn{3}{|c|}{ Women } \\
\hline & Freq. & $\begin{array}{l}\text { Downward } \\
\text { Mobility vs } \\
\text { Lateral Mobility } \\
\operatorname{Exp}(ß)\end{array}$ & $\begin{array}{c}\text { Upward } \\
\text { Mobility vs } \\
\text { Lateral Mobility } \\
\operatorname{Exp}(ß)\end{array}$ & Freq. & $\begin{array}{l}\text { Downward } \\
\text { Mobility vs } \\
\text { Lateral Mobility } \\
\text { Exp(ß) }\end{array}$ & $\begin{array}{c}\text { Upward } \\
\text { Mobility vs } \\
\text { Lateral Mobility } \\
\operatorname{Exp}(ß)\end{array}$ \\
\hline \multicolumn{7}{|l|}{ Area of Birthplace } \\
\hline Latin America & 1,425 & 1 & 1 & 1,748 & 1 & 1 \\
\hline EU-25 & 427 & $0.31^{\star \star \star}$ & $2.11^{\star \star}$ & 394 & $0.18^{\star \star \star}$ & $1.33^{\star \star \star}$ \\
\hline Rest of Europe & 703 & $0.85^{\mathrm{ns}}$ & $0.60^{\star \star}$ & 675 & $1.27^{\star \star}$ & $1.17^{\star}$ \\
\hline Africa & 687 & $2.21^{\star \star \star}$ & $0.70^{\star}$ & 143 & $0.79^{\mathrm{ns}}$ & $1.07^{\star}$ \\
\hline North America and Oceania & 21 & $0.11^{\star \star \star}$ & $2.88^{\mathrm{ns}}$ & 12 & $0.92^{\mathrm{ns}}$ & $3.34^{\mathrm{ns}}$ \\
\hline Asia & 104 & $1.26^{\text {ns. }}$ & $0.40^{\mathrm{ns}}$ & 47 & $0.47^{\mathrm{ns}}$ & $1.04^{\mathrm{ns}}$ \\
\hline \multicolumn{7}{|l|}{ Socio-demographic characteristics } \\
\hline \multicolumn{7}{|l|}{ Age on arrival } \\
\hline 20-34 & 2,387 & 1 & 1 & 2,049 & 1 & 1 \\
\hline $35-44$ & 708 & $0.75^{\star}$ & $0.70^{\mathrm{ns}}$ & 651 & $0.89^{\mathrm{ns}}$ & $0.84^{\mathrm{ns}}$ \\
\hline $45-54$ & 224 & $0.74^{\star \star}$ & $1.28^{\mathrm{ns} .}$ & 275 & $1.12^{\mathrm{ns} .}$ & $0.92^{\mathrm{ns}}$ \\
\hline $55-64$ & 48 & $0.44^{\star \star}$ & $1.03^{\mathrm{ns} .}$ & 44 & $0.95^{\mathrm{ns}}$ & $1.33^{\mathrm{ns}}$ \\
\hline \multicolumn{7}{|l|}{ Educational Level } \\
\hline Primary or lower & 966 & $1.37^{\star \star \star}$ & $0.37^{\star \star \star}$ & 607 & $2.28^{\star \star \star}$ & $0.37^{\star \star \star}$ \\
\hline Secondary & 1,816 & $1.66^{\star \star \star}$ & $0.68^{\star \star}$ & 1,661 & $2.40^{\star \star \star}$ & $0.80^{\text {ns. }}$ \\
\hline Universitary & 585 & 1 & 1 & 751 & 1 & 1 \\
\hline \multicolumn{7}{|l|}{ Family characteristics } \\
\hline \multicolumn{7}{|l|}{ Partnership on arrival } \\
\hline Partner already in Spain & 126 & 1 & 1 & 273 & 1 & 1 \\
\hline No partner & 1,483 & $0.67^{\text {ns. }}$ & $0.67^{\mathrm{ns} .}$ & 1,598 & $0.76^{\mathrm{ns}}$ & $1.47^{\mathrm{ns} .}$ \\
\hline Partner other circumstances & 1,758 & $0.68^{\mathrm{ns} .}$ & $1.03^{\mathrm{ns} .}$ & 1,148 & $0.76^{\mathrm{ns}}$ & $1.70^{\mathrm{ns} .}$ \\
\hline \multicolumn{7}{|l|}{ Children on migration } \\
\hline No children & 1,791 & 1 & 1 & 1,319 & 1 & 1 \\
\hline Children & 1,576 & $0.96^{\mathrm{ns}}$ & $0.71^{\mathrm{ns}}$ & 1,700 & $2.09^{\star \star \star}$ & $0.88^{\mathrm{ns}}$ \\
\hline \multicolumn{7}{|l|}{ Role of social network } \\
\hline \multicolumn{7}{|l|}{ Method of seeking the first job } \\
\hline Formal methods & 1,079 & 1 & 1 & 1,043 & 1 & 1 \\
\hline Family and friends & 2,288 & $2.00^{\star \star \star}$ & $1.23^{\mathrm{ns}}$ & 1,976 & $2.09^{\star \star \star}$ & $0.88^{\mathrm{ns}}$ \\
\hline \multicolumn{7}{|l|}{ Occupation in country of origin } \\
\hline Managerial occupation & 229 & $4.55^{\star \star \star}$ & 0.00ns. & 164 & $10.06^{\star \star \star}$ & $0.00^{\text {ns. }}$ \\
\hline Technical and Professional occupation & 544 & $2.50^{\star \star \star}$ & $0.05^{\star \star \star}$ & 802 & $4.74^{\star \star \star}$ & $0.13^{\star \star \star}$ \\
\hline Skilled occupation & 1,415 & $0.67^{\star \star}$ & $0.04^{\star \star \star}$ & 429 & $3.50^{\star \star \star}$ & $0.30^{\star \star}$ \\
\hline Administrative and Secretarial occupation & 145 & $5.22^{\star \star \star}$ & $3.28^{\star \star \star}$ & 372 & $8.39^{\star \star \star}$ & $2.82^{\star \star \star}$ \\
\hline Services occupation & 489 & 1 & 1 & 867 & 1 & 1 \\
\hline Elementary occupation & 545 & $0.00^{\mathrm{ns} .}$ & $0.43^{\star \star \star}$ & 385 & $0.00^{\mathrm{ns}}$ & $1.14^{\mathrm{ns}}$ \\
\hline \multicolumn{7}{|l|}{ Dependent variable: Labour mobility } \\
\hline Lateral (baseline category) & 1,494 & & & 830 & & \\
\hline Downward & 1,446 & & & 1,948 & & \\
\hline \multirow[t]{3}{*}{ Upward } & 427 & & & 241 & & \\
\hline & & -2 log likehood & 2,182 & & -2 log likehood & 1,758 \\
\hline & & Chi-Square & $1,683^{\star \star \star}$ & & Chi-Square & $1,554^{\star \star \star}$ \\
\hline
\end{tabular}

Data source: National Immigrant Survey 2007 (ENI-2007).

Statistic significance $=$ "ns" non significant; *: $p<0,10 ; *$ * $p<0,05 ;{ }^{* \star *}$ : $p<0,01$. 
The effects of the variables related to a woman's educational attainment, the number of children she had at the time of migration, and the methods she used in searching for a first job followed patterns that were similar to those obtained in the female downward model. Indeed, the higher a woman's educational attainment, the lower the probability was that her first job would be in domestic services. Moreover, having children and finding a job through friends and family substantially increased the probability of having a first job in domestic services. Hence, the informality of the hiring process in domestic and cleaning services is supported for these coefficients. Nevertheless, unlike in the previous models, we see here that a woman whose partner preceded her in migrating to Spain was less likely to work as a domestic assistant, and that there was a positive association of age, at least until the age of 54. Finally, the results show that a woman's occupational category before she migrated did not affect the likelihood that her first job post-migration would be in domestic services, unless the woman had already been employed in a cleaning or domestic occupation in her country of origin. As expected, we found that this latter type of migrant had three times the risk of experiencing lateral mobility. Therefore, these results contradict the human capital theoretical postulates, and point to a segmentation explanation for the tendency among immigrant women to enter the labour market as a domestic worker.

Table 5: Likelihood of entering the labour market in Spain as a domestic worker: coefficients of the logistic regression models. Immigrant women

\begin{tabular}{|c|c|c|c|c|}
\hline Variables & Freq. & $\operatorname{Exp}(ß)$ & Freq. & $\operatorname{Exp}(ß)$ \\
\hline \multicolumn{5}{|l|}{ Area of Birthplace } \\
\hline Latin America & 1,891 & 1 & 1,748 & 1 \\
\hline EU-25 & 417 & $0.09^{* \star \star}$ & 394 & 0.09 *** \\
\hline Rest of Europe & 743 & $0.73^{\star \star}$ & 675 & $0.81^{\star \star}$ \\
\hline Africa & 174 & $0.48^{* \star \star}$ & 143 & $0.49^{\star \star *}$ \\
\hline North America and Oceania & 12 & $0.04^{\star \star}$ & 12 & $0.05^{\star \star}$ \\
\hline Asia & 52 & $0.14^{\star \star \star}$ & 47 & $0.16^{\star \star \star}$ \\
\hline \multicolumn{5}{|c|}{ Socio-demographic characteristics } \\
\hline \multicolumn{5}{|c|}{ Age on arrival } \\
\hline $20-34$ & & & 2,049 & 1 \\
\hline $35-44$ & & & 651 & $1.32^{\star \star *}$ \\
\hline $45-54$ & & & 275 & $2.05^{\star \star \star}$ \\
\hline $55-64$ & & & 44 & $0.82^{\mathrm{ns} .}$ \\
\hline \multicolumn{5}{|l|}{ Educational Level } \\
\hline Primary or lower & & & 607 & $2.22^{\star \star \star *}$ \\
\hline Secondary & & & 1,661 & $2.06^{\star \star *}$ \\
\hline University & & & 751 & 1 \\
\hline
\end{tabular}


Table 5: (Continued)

\begin{tabular}{|c|c|c|c|}
\hline \multirow{2}{*}{$\begin{array}{l}\text { Variables } \\
\text { Family characteristics }\end{array}$} & \multirow[t]{2}{*}{ Freq. $\operatorname{Exp}(ß)$} & \multicolumn{2}{|c|}{ Freq. $\operatorname{Exp}(ß)$} \\
\hline & & & \\
\hline \multicolumn{4}{|l|}{ Partnership on arrival } \\
\hline Partner already in Spain & & 273 & 1 \\
\hline No partner & & 1,598 & $1.19^{\text {ns. }}$ \\
\hline Partner other circumstances & & 1,148 & 1.13 \\
\hline \multicolumn{4}{|l|}{ Children at migration } \\
\hline No children & & 1,319 & 1 \\
\hline Children & & 1,700 & $1.22^{\star \star}$ \\
\hline \multicolumn{4}{|l|}{ Role of social network } \\
\hline \multicolumn{4}{|l|}{ Method of seeking the first job } \\
\hline Formal methods & & 1,043 & 1 \\
\hline Family and friends & & 1,976 & $1.50^{\star \star \star}$ \\
\hline \multicolumn{4}{|l|}{ Occupation in country of origin } \\
\hline Managerial occupation & & 164 & $1.19^{\text {ns. }}$ \\
\hline Technical and Professional occupation & & 802 & $1.37^{\text {ns. }}$ \\
\hline Skilled occupation & & 429 & $1.15^{\text {ns. }}$ \\
\hline Administrative and Secretarial occupation & & 372 & $1.18^{\text {ns. }}$ \\
\hline Services occupation & & 867 & 1 \\
\hline Elementary occupation & & 216 & $1.10^{\mathrm{ns} .}$ \\
\hline Cleaning and Domestic occupation & & 169 & $2.95^{\star \star \star}$ \\
\hline Constant & $1.02^{\text {ns. }}$ & & $0.24^{\star \star \star}$ \\
\hline-2 log likehood & 4,197 & & 3,703 \\
\hline Chi-Square & $290 * * \star$ & & $413^{\star \star \star}$ \\
\hline
\end{tabular}

Data source: National Immigrant Survey 2007 (ENI-2007).

\subsection{The labour mobility of immigrant women as they settled in Spain: leaving the cleaning and domestic occupations}

Table 6 displays the mobility matrix for immigrant women after migration, from their initial occupation to their occupation at the time of the interview. The positive values of the adjusted standardised residuals in the diagonal and the marginal percentages lead us to conclude that the immigrant women had a high probability of maintaining the same occupational category during their time in the Spanish labour market, either because they remained in the first job they got in Spain (frequencies between parentheses in the diagonal), or because they changed jobs but not their occupational status. Among all of the immigrant women studied, $28.1 \%$ worked as a domestic in their first job in Spain and remained in the same labour category until the time of the survey. Service 
occupations (12.7\%) was the second-most common occupational category among the immigrant women who experienced no occupational mobility, followed by elementary (unskilled) occupations (8.6\%), and technical and professional occupations (7.2\%). However, it is also possible to identify a weak general trend towards upward mobility, especially among women who left the cleaning and domestic occupations for other types of positions. Indeed, when we looked at the percentages in the margins, we found that the largest decrease (of 14.1 percentage points) was among immigrant women working in cleaning and domestic occupations, from $45.9 \%$ at the country of origin to $31.8 \%$ upon arrival in Spain. Meanwhile, the percentages related to all of the other labour positions increased. Thus, our second conclusion is that some upward occupational mobility did occur, but that this trend was weak and specific to mobility from cleaning and domestic occupations to other occupations within the secondary segment, mostly to service work or other elementary occupations.

The descriptive results indicate that the women in cleaning and domestic occupations experienced one of the strongest outflows to services and other elementary occupations. Therefore, we constructed two multivariate binary logistic regression models (Table 7) designed to evaluate the influence of socio-demographic and family characteristics, as well as the role of legal status and the importance of the assimilation process to the host society, on the probability that domestic workers would have left domestic services to take on other labour positions. The outcome variable in the models is a dummy variable with a value equal to zero for those who reported that they were still working as a domestic assistant, and a value equal to one otherwise. In the second model, we also controlled for the duration of stay in Spain (years), which is considered a key factor in the likelihood of leaving domestic services and experiencing upward labour mobility.

The results show that among non-communitarian European, African, and Asian women, the likelihood that they would have left a domestic position was not statistically different from that of Latin American women, the reference group. By contrast, women from the EU-25 had the lowest probability of leaving domestic services (0.42). We assume that this result reflects the presence of Portuguese women, who started moving to Spain to work in domestic services before the 1990s (Borderías and Azcárate 1994). According to Borderías and Azcárate, very poor and low-skilled Portuguese women from rural areas made up a large share of immigrant domestic workers in Spain during the 1980s, when most of these women were working in the country irregularly prior to the full integration of Spain and Portugal into the European Union. However, the share of Portuguese women among domestic workers in Spain decreased as a consequence of the acceleration of non-EU female immigration flows during the 1900s, and especially during the 2000s. 
Table 6: Total relative distribution matrix of the first occupation in Spain and the current occupation at the time of the interview. Immigrant women who arrived from 1999 to 2007 and were aged 16-64 at arrival.

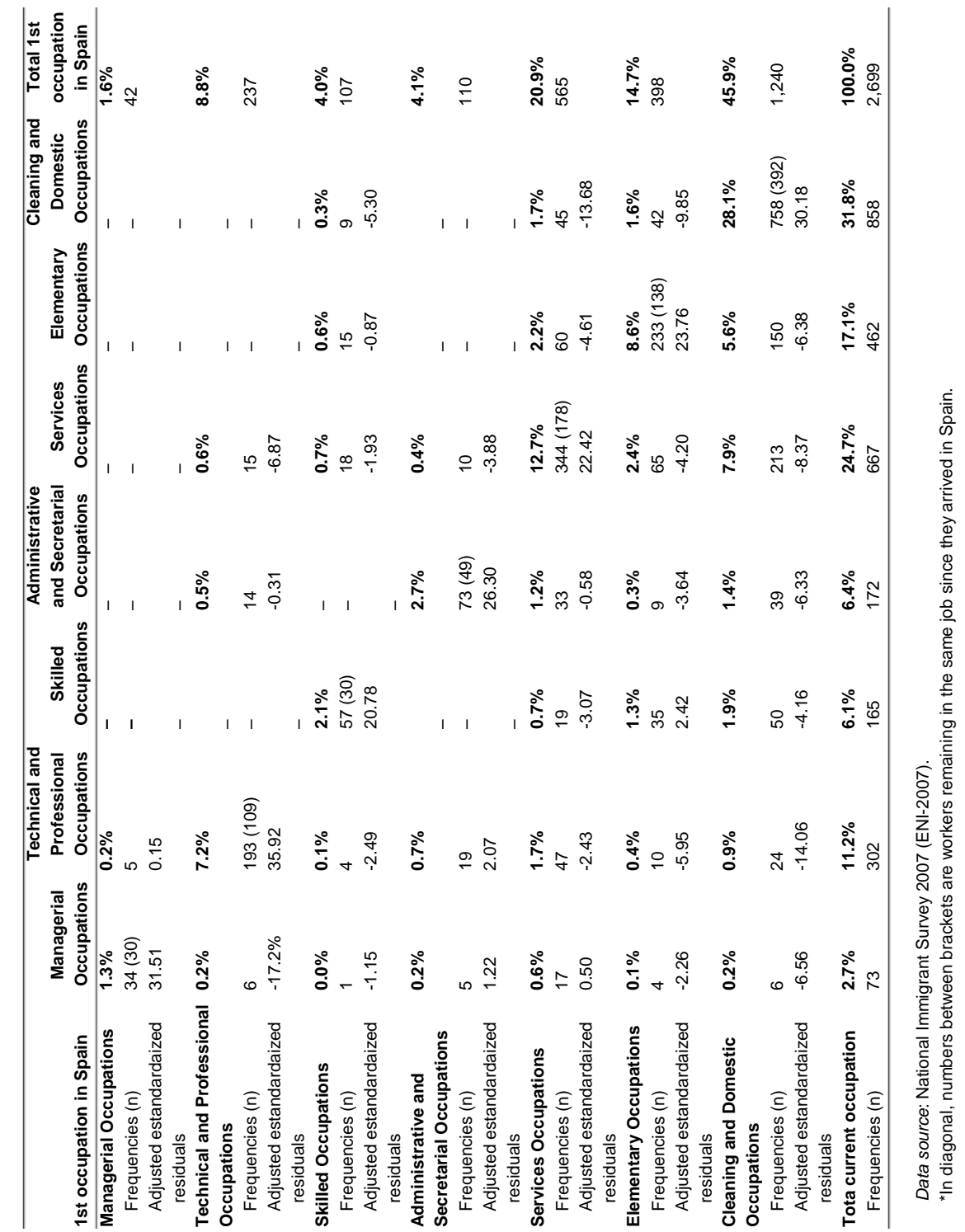


The influence of the age upon arrival on the propensity to leave domestic services is clear: the probability decreased with age. Thus, we can confirm our hypothesis that the women who arrived at an early stage in their labour market career were more able to access other kinds of jobs. The results by educational level are consistent with those expected by human capital theory: i.e., the higher the woman's level of education, the higher the probability that she had left the cleaning and domestic occupations. These results indicate that the highly skilled women who entered the Spanish workforce as a domestic assistant had better chances of upward mobility after they had been living in Spain for a period of time. In line with human capital theory, the women who reported having obtained or validated an educational degree in Spain (1.91) had higher odds of abandoning domestic work. However, speaking Spanish or another co-official language did not have a significant influence on the likelihood that an immigrant domestic worker would have moved to another kind of occupation. Our interpretation of this finding is that it reflects a preference among Latin American women for care and domestic work.

With regard to family characteristics, a woman with a partner who lived elsewhere was less likely to have abandoned domestic services than a woman without a partner or who was cohabitating with a partner. We interpret this finding as being the consequence of the family migratory strategies of the women who arrived without their partner, and who accepted work in domestic services because was the easiest way to regularise their situation and save money in order to facilitate future family reunification processes. The analysis also indicated that it was not just the presence of the partner that mattered, but also his country of origin, as having contact with natives may play a particularly important role in an immigrant's labour market status (Kanas and Van Tubergen 2009). Our results confirmed our assumption that a woman with a Spanish-born partner would have had a much higher likelihood of abandoning domestic and cleaning work. Moreover, as expected, we found that immigrant women with legal residence status were more likely to have abandoned domestic services work than those who were living in Spain without authorisation. At the same time, and contrary to expectations, we found that having children was not a significant explanatory characteristic of our outcome variable.

The final covariate we investigated was length of stay in Spain (years since immigration). The results are clear: the probability of leaving the cleaning and domestic occupations was directly related to the length of time spent in Spain. The domestic workers who had been living in Spain for two years had an odds ratio of 4.13 relative to those who had been living in Spain for less than a year (the reference category), while those who had been living in Spain for more than five years had an odds ratio of 8.44.

The relationship between the duration of stay and the outcome variable becomes even clearer when we look at the model's constant before and after including this 
variable. In the first model, the value of the constant was 0.56 . After controlling by the length of the stay, the value decreased to 0.10 , as we chose as the reference group women who had arrived very recently.

\section{Conclusion and discussion}

In this paper, we demonstrate that female immigration to Spain and the types of jobs foreign-born women take upon entering the Spanish labour market are shaped by the gender segmentation of the labour market and the insufficient supply of native women for unskilled jobs, especially in domestic and cleaning roles in private households. Thus, in line with the qualitative research of "Colectivo Ioe" (2003), Parella (2003), and Oso (2003), we predicted we would find that the most common labour trajectory for a female immigrant, regardless of her previous labour market experience or human capital, would be entering the Spanish labour market as a domestic worker, and later leaving this position to work in another occupation in Spain's secondary labour market, such as in hotels, restaurants, personal services, and other unskilled occupations.

Table 7: Likelihood of leaving the cleaning and domestic occupations: coefficients of the logistic regression models. Immigrant women

\begin{tabular}{|c|c|c|c|}
\hline & Freq. & $\begin{array}{c}\text { Model 1 } \\
\operatorname{Exp}(ß)\end{array}$ & $\begin{array}{c}\text { Model } 2 \\
\operatorname{Exp}(ß)\end{array}$ \\
\hline \multicolumn{4}{|l|}{ Area of Birthplace } \\
\hline Latin America & 830 & 1 & 1 \\
\hline EU-25 & 36 & $0.42^{* *}$ & $0.43^{\star \star}$ \\
\hline Rest of Europe & 287 & $0.71^{\text {ns. }}$ & $0.84^{\mathrm{ns} .}$ \\
\hline Africa & 33 & $1.31^{\mathrm{ns} .}$ & $1.16^{\mathrm{ns} .}$ \\
\hline Asia & 9 & $1.16^{\text {ns. }}$ & $1.04^{\text {ns. }}$ \\
\hline \multicolumn{4}{|c|}{ Socio-demographic characteristics } \\
\hline \multicolumn{4}{|c|}{ Age on arrival } \\
\hline 20-34 & 728 & 1 & 1 \\
\hline $35-44$ & 304 & $0.56^{* * *}$ & $0.55^{\star \star \star}$ \\
\hline $45-64$ & 163 & $0.35^{\star \star *}$ & $0.35^{\star \star \star}$ \\
\hline \multicolumn{4}{|l|}{ Educational level } \\
\hline Primary or lower & 271 & 1 & 1 \\
\hline Secondary & 705 & $1.95^{\star \star \star}$ & $1.90 * * \star$ \\
\hline University & 219 & $3.01^{\star * \star}$ & $3.16^{\star \star \star}$ \\
\hline
\end{tabular}


Table 7: Likelihood of leaving the cleaning and domestic occupations: coefficients of the logistic regression models. Immigrant women

\begin{tabular}{|c|c|c|c|}
\hline & Freq. & $\begin{array}{c}\text { Model } 1 \\
\operatorname{Exp}(ß)\end{array}$ & $\begin{array}{c}\text { Model } 2 \\
\operatorname{Exp}(ß)\end{array}$ \\
\hline \multicolumn{4}{|c|}{ Speaks Spanish or regional language } \\
\hline No & 28 & 1 & 1 \\
\hline Yes & 1,167 & $0.20^{\text {ns. }}$ & $0.27^{\text {ns. }}$ \\
\hline \multicolumn{4}{|c|}{ Education finished/validated in Spain } \\
\hline No & 1,115 & 1 & 1 \\
\hline Yes & 80 & $1.91^{* * *}$ & $1.83^{\star \star}$ \\
\hline \multicolumn{4}{|l|}{ Family characteristics } \\
\hline \multicolumn{4}{|l|}{ Partnership (currently) } \\
\hline No partner & 671 & 1 & 1 \\
\hline Partner living apart & 117 & $0.46^{\star \star \star}$ & $0.49^{\star \star \star}$ \\
\hline Cohabiting with the partner & 407 & $0.81^{\star \star}$ & $0.78^{\star \star}$ \\
\hline \multicolumn{4}{|l|}{ Partner country of birth } \\
\hline No partner & 468 & 1 & 1 \\
\hline Spain & 156 & $2.59^{\star \star \star}$ & $2.43^{\star \star \star}$ \\
\hline Immigrant, same country & 532 & $1.49^{*}$ & $1.60^{\star \star \star}$ \\
\hline Immigrant, other country & 39 & $2.32^{\star}$ & $2.42^{*}$ \\
\hline \multicolumn{4}{|l|}{ Children (currently) } \\
\hline No children & 283 & 1 & 1 \\
\hline Children & 912 & $0.99^{\text {ns. }}$ & $0.89^{\text {ns. }}$ \\
\hline \multicolumn{4}{|l|}{ Legal status (currently) } \\
\hline Regular residence in Spain & 966 & 1 & 1 \\
\hline Irregular residence in Spain & 229 & $0.14^{\star \star \star}$ & $0.26^{\star \star \star}$ \\
\hline \multicolumn{4}{|l|}{ Years from migration } \\
\hline Less than 1 year & 82 & & 1 \\
\hline 1 year & 105 & & $1.96^{\mathrm{ns}}$ \\
\hline 2 years & 135 & & $4.13^{\star \star \star}$ \\
\hline 3 years & 131 & & $4.71^{\star \star \star}$ \\
\hline 4 years & 159 & & $3.67^{\star \star \star}$ \\
\hline 5 years & 201 & & $6.85^{\star \star \star}$ \\
\hline More than 5 years & 382 & & $8.44^{\star \star *}$ \\
\hline Constant & & $0.56^{\star \star \star}$ & $0.10^{\star \star \star}$ \\
\hline-2 log likehood & & 1,354 & 1,295 \\
\hline Chi-Square & & $241^{\star \star \star}$ & $299 * * *$ \\
\hline
\end{tabular}

Data source: National Immigrant Survey 2007 (ENI-2007). 
Our analysis revealed that while both male and female immigrants experienced a decline in occupational status upon entering the Spanish labour market, women were at greater risk than men of moving into a lower occupational category, even after controlling for a set of explanatory variables. This conclusion is in line with previous findings from Stanek and Veira (2009) and Vono and Vidal-Coso (2012). Thus, even if both men and women tend to enter the Spanish labour market in the secondary segment - a common segmentation pattern - this is especially the case for female migrants. Concretely, our mobility table demonstrates that industry and occupational concentration in the first job after migration was particularly pronounced among women, as $41.6 \%$ of them were working in cleaning and domestic services; whereas men were more evenly distributed along the occupational scale. However, although our focus in this paper has been on changes in occupational status from the country of origin to the country destination, we acknowledge that social mobility is not determined by occupational status alone. Other elements that are important for understanding migrants' strategies likely include the difference between the wages they earned in Spain and the wages they earned prior to migration, their relative access to social services, and their relative access to professional training courses.

Finally, our results demonstrated that, despite the high proportion of occupational continuity, employment in domestic services was not an irreversible labour status, and that upward occupational mobility was possible for the most assimilated immigrant women; i.e., those with legal residence in the country. These findings correspond with those of Akresh (2006, 2008); Chiswick (1978); and Chiswick, Lee, and Miller (2005).

The multivariate regression analysis also confirmed our assumption that non-EU European and Latin American women were at greatest risk of losing their occupational status upon migration, whereas women from the EU-25, North America and Oceania were more likely to have improved their occupational status. These findings are in line with structural or segmentation theory, and with the "ethnic penalty" identified by Heath and Cheung (2007). The results also show that age on arrival and partnership status did not have significant effects on the direction of labour mobility among immigrant women, but that these factors were clearly related to the likelihood of entering the Spanish labour market as a domestic worker (Oso 2003). Furthermore, the results of the models demonstrate that a woman who had children at the time of migration was more likely to have lost her occupational status, as she would have been less able than a woman without children to have been selective in her initial job selection in Spain. We also note that the assumptions of human capital theory regarding the role of individuals' educational attainment and labour experience (Becker 1962, 1964; Borjas 1994; Chiswick and Miller 2002) were only partly verified with regard to labour mobility. Indeed, the findings indicate that migration to Spain was generally favourable for women with the highest educational levels, whereas the labour market 
experience of women prior to migration had little effect on the first job they took in Spain. In fact, women who were at the top of the occupational structure in their country of origin were especially disadvantaged post-migration. Finally, the use of migrant networks as a resource for seeking employment was found to have been linked to downward mobility, in line with the results of Portes and Sensenbrenner (1993) and Mahuteau and Junakar (2008). Our interpretation of this finding is supported by social capital theorists: i.e., informal networks tend to steer immigrants towards informal jobs which are largely situated at the bottom of the occupational scale, especially those that entail cleaning or domestic services in private households. Therefore, the role of migrant networks in providing labour market opportunities for female migrants in Spain was highly associated with domestic service jobs. By contrast, women who found their first job after arriving in Spain using formal methods were more likely to have improved their occupational category.

Finally, after examining the immigrants' labour mobility since arrival (i.e., during residence in Spain), the analysis showed that mobility was very limited and restricted to labour market positions in the secondary segment; in line with the findings of AysaLastra and Cachon (2013). In general, there is a clear trajectory in which domestic workers go on to work in other personal service sectors, such as in hotel or restaurant jobs, or in other unskilled or elementary jobs. One of the main factors associated with this type of mobility was the length of residence in Spain: the likelihood of leaving domestic work rose with the amount of time spent in the country. The other key factors in this occupational trajectory were related to assimilation into Spanish society, as measured by the acquisition of post-migration education, having a Spanish-born partner, and having legal status; as women with legal residency were more likely to leave domestic work. In this sense, female immigration in Spain is the product of two pull factors which are common throughout southern Europe: the increase in demand for housekeepers or carers for the elderly, and the ex post regularisations of immigrants, in lieu of the ex ante planning of migration flows (Bettio, Zimonazzi, and Villa 2006: 275). The occupational downgrading of foreign-born women immediately after migration to Spain may therefore be a consequence of the fact that most of them enter the country illegally, which clearly complicates their access to skilled occupations. We can assume that many of these women opted to work irregularly as a domestic maid due to the informality of the hiring process, while expecting that they would eventually be able to secure status through one of the retroactive amnesties the Spanish government has periodically granted. This process has been described for Italy by Fullin and Reynery (2011) and Venturini and Villosio (2008). Furthermore, the difficulties involved in having their educational qualifications obtained abroad recognised in the destination country explains why even highly qualified immigrant women may be unable to get a skilled job upon arrival (Bernardi, Garrido and Miyar, 2011). 
Nonetheless, since many of the immigrant women surveyed in 2007 had arrived in Spain fairly recently, it is possible that the weak labour mobility we observed could change. Thus, it may be useful to wait until more immigrant women have spent more time in the Spanish labour force and in Spanish society before drawing conclusions about their career prospects.

Finally, we should close this paper by stressing the importance of the changing socio-economic context in Spain, as the country's economy has shifted abruptly from rapid expansion to deep recession. The vulnerability of immigrant workers during periods of economic contraction has been well-analysed (e.g., the OECD (2002) of immigrant employment). However, the focus of our study differs markedly from that of previous studies, which have mainly looked at male migration. Although female migrants share some of the same vulnerabilities as male migrants in the destination labour market, the sector in which they are employed (primarily domestic services) has been less severely affected by the economic crisis than traditionally male occupational sectors (Vidal-Coso, Gil, and Domingo 2012). It is likely that, despite the new economic environment, most native families will continue to face the same challenges in balancing work and family, and that hiring immigrant women to help in the household will continue to be seen as the main solution. However, although the demand for immigrant domestic helpers will depend heavily on the level of services provided from the welfare state programs, the evolution of the employment crisis is also a crucial factor. In fact, in the most recent phase of the economic crisis, unemployment has started to affect traditionally female occupations, especially those related to education, health services, and public administration. Therefore, we expect that a deterioration in the job opportunities of native women will affect the demand for domestic services over the medium to long term. Finally, it is unclear whether the current situation, in which unemployment has risen substantially across the Spanish labour market, will result in more pronounced and direct competition between less skilled native and immigrant women. Accordingly, future research should examine the effects of the economic crisis on the social mobility prospects of immigrants.

\section{Acknowledgments}

This research has received economic support from the $2010 \mathrm{R}+\mathrm{D}$ Programme of the Spanish Ministry of Sciences and Innovation for the "Labour market dynamic and family formation in Spain during the turn of the century" (Dinámica del mercado de trabajo y formación familiar en España durante el cambio de siglo) / (Reference CSO2010-21028/SOCI) and the "Multiple Equilibrium Analysis of Family" (Análisis de multiples equilibrios en la familia) / (Reference CSO2010-19062/SOCI) projects. 


\section{References}

Akresh, I.R. (2006). Occupational Mobility Among Legal Immigrants to the United States. International Migration Review 40(4): 854-884. doi:10.1111/j.17477379.2006.00046.x.

Akresh, I.R. (2008). Occupational Trajectories of Legal US Immigrants: Downgrading and Recovery. Population and Development Review 34(3): 435-456. doi:10. 1111/j.1728-4457.2008.00231.x.

Amuedo-Dorantes, C. and De La Rica, S. (2009). Labour market assimilation of recent immigrants in Spain. IZA discussion paper 2014 April. Bonn: IZA.

Anguiano, M.E. (2001). Inmigración laboral extracomunitaria en España: explorando perfiles y trayectorias laborales. Migraciones 10 (December): 111-134.

Anthias, F. and Lazaridis, G. (2000). Gender and Migration in Southern Europe. Oxford: Berg.

Aysa-Lastra, M. and Cachón, L. (2013). Determinantes de la movilidad ocupacional segmentada de los inmigrantes no comunitarios en España. Revista internacional de sociología 71(2): 383-413. doi:10.3989/ris.2013.i2.

Barone, G. and Mocetti, S. (2011). With a little help from abroad: the effect of lowskilled immigration in female labour supply. Labour Economics 18(5): 664-675. doi:10.1016/j.labeco.2011.01.010.

Becker, G.S. (1962). Investment in human capital: a theoretical analysis. Journal of Political Economy. 70(5): 9-49. doi:10.1086/258724.

Becker, G.S. (1964). Human capital: a theoretical and empirical analysis, with special reference to education. New York: National Bureau of Economic Research.

Berman, E., Lang, K., and Siniver, E. (2003). Language-skill Complementarity: Returns to Immigrant Language Acquisition. Labour Economics 10(3): 265-290. doi:10. 1016/S0927-5371(03)00015-0.

Bernardi, F. and Garrido, L. (2008). Is There a New Service Proletariat? Post-industrial Employment Growth and Social Inequality in Spain. European Sociological Review 24(3): 299-313. doi:10.1093/esr/jcn003.

Bernardi, F., Garrido, L., and Miyar, M. (2011). The Recent Fast Upsurge of Immigrants in Spain and Their Employment Patterns and Occupational Attainment. International Migration 49(1): 148-187. doi:10.1111/j.1468-2435. 2010.00610.x. 
Bernardi, F. and Martínez-Pastor, J.I. (2010). Falling at the bottom: Unskilled Jobs at entry in the labour market in Spain over time and in a comparative perspective. International Journal of Comparative Sociology 51(4): 289-307. doi:10.1177/ 0020715210368841.

Bettio, F., Simonazzi, A., and Villa, P. (2006). Change in care regimes and female migration: the care drain in the Mediterranean. Journal of European Social Policy 16(3): 271-285. doi:10.1177/0958928706065598.

Blackaby, D.H., Leslie, D.G., Murphy, P.D., and O’Leary, N.C. (2002). White/Ethnic Minority and Employment Differentials in Britain: Evidence from the LFS. Oxford Economic Papers 54(2): 270-297. doi:10.1093/oep/54.2.270.

Bleakley, H. and Chin, A. (2004). Language Skills and Earnings: Evidence from Childhood Immigrants. Review of Economics and Statistics 86(2):481-496. doi:10.1162/003465304323031067.

Blau, P. and Duncan, O.D. (1967). The American Occupational Structure. New York: The Free Press.

Borderías, M.P. and Azcárate, M.V. (1994). Mujeres inmigrantes en España. El caso de las mujeres portuguesas. Espació, Tiempo y Forma, Serie VI, Geografia (7): 3750.

Borjas, G. (1994). The Economics of Immigration. Journal of Economic Literature 32(4): 1667-1717.

Cachón, L. (1989). ¿Movilidad social o trayectorias de clase? Elementos para una crítica de la sociología de la movilidad social. Madrid: Centro de Investigaciones Sociológicas, Siglo XXI.

Cachón, L. (2002). La formación de la "España inmigrante”: mercado y ciudadanía. Reis: Revista española de investigaciones sociológicas 97: 95-126.

Cachón, L. (2009). La "España inmigrante": marco discriminatorio, mercado de trabajo y políticas de integración. Rubí (Barcelona): Anthropos.

Clark, K. and Drinkwater, S. (2008). The labour-market performance of recent migrants. Oxford Review of Economic Policy 24(3): 495-516. doi:10.1093/ oxrep/grn023.

Chiswick, B.R. (1978). The Effect of Americanization on the Earnings of Foreign-Born Men. Journal of Political Economy 85(5): 897-921. doi:10.1086/260717. 
Chiswick, B.R., Lee, Y., and Miller, P. (2005). A Longitudinal Analysis of Immigrant Occupational Mobility: A Test of the Immigrant Assimilation Hypothesis. International Migration Review 39(2): 332-353. doi:10.1111/j.1747-7379.2005. tb00269.x.

Chiswick, B.R. and Miller, P. (2002). Immigrants Earnings: Language Skills, Linguistic Concentrations and the Business Cycle. Journal of Economy and Society 48(3): 454-465.

Colectivo IOE (2003). Mujeres inmigradas y trabajo. In: Checa, F. (ed.). Mujeres en el camino. El fenómeno de la migración femenina en España. Barcelona: Icaria editorial: $15-54$.

Dustmann, C. and Fabbri, F. (2003). Language Proficiency and Labour Market Performance of Immigrants in the UK. Economic Journal 113(489): 695-717. doi:10.1111/1468-0297.t01-1-00151.

Ekberg, J. (1994). Economic progress among immigrants in Sweden. Scandinavian Journal of Social Welfare 3(3): 148-157. doi:10.1111/j.1468-2397.1994.tb000 73.x.

Ekberg, J. (1996). Labour market career among young Finnish immigrants in Sweden. International Migration Quarterly Review 34(3): 371-384. doi:10.1111/j.14682435.1996.tb00533.x.

Escrivà, A. (2000). ¿Empleadas de por vida? Peruanas en el servicio doméstico de Barcelona. Papers, revista de sociología 60: 327-342.

Finotelli, C. (2007). Italia, España y el modelo migratorio mediterráneo en el siglo $X X I$. Madrid: Real Instituto Elcano.

Fullin, G. and Reyneri, E. (2011). Low Unemployment and Bad Jobs of New Immigrants in Italy. International Migration 49(1): 118-147. doi:10.1111/j. 1468-2435.2009.00594.x.

Goldthorpe, J.H. (1980). Social mobility and class structure in modern Britain. Oxford: Clarendon Press.

Goldthorpe, J.H. and Hope, K. (1974). The Social Grading of Occupations. A New Approach and Scale. Oxford: Clarendon Press.

Heath, A. and Cheung, S.-Y. (2007). Unequal Chances. Ethnic Minorities in Western Labour Markets. Oxford: Oxford University Press. doi:10.5871/bacad/97801972 63860.001 .0001 . 
Hope, K. (1972). The Analysis of Social Mobility. Methods and approaches. Oxford: Clarendon Press.

Hugo, G. (1981). Village-Community Ties, Village Norms and Ethnic and Social Networks: A Review of Evidence from the Third World. In: DeJong F.G. and Gardner R.W. (eds.). Migration Decision Making: Multidisciplinary Approaches to Microlevel Studies in Developed and Developing Countries. New York: Pergamon Press. doi:10.1016/B978-0-08-026305-2.50013-9.

Kalleberg, A.L. and Sorensen, A.B. (1979). The sociology of labor markets. Annual Review of Sociology 5(1): 351-379. doi:10.1146/annurev.so.05.080179.002031.

Kanas, A., Chiswick, B.R., van der Lippe, T., and van Tubergen, F. (2012). Social Contacts and the Economic Performance of Immigrants: A Panel Study of Immigrants in Germany. International Migration Review 46(3): 680-709. doi:10.1111/j.1747-7379.2012.00901.x.

Kanas, A. and van Tubergen, F. (2009). The Impact of Origin and Host Country Schooling on the Economic Performance of Immigrants. Social Forces 88(2): 893-915. doi:10.1353/sof.0.0269.

Kee, P. (1995). Native-Immigrant Wage Differentials in the Netherlands: Discrimination?. Oxford Economic Papers 47:302-317.

King, R., Lazaridis, G., and Tsardanidis, C. (2000). Eldorado or Fortress? Migration in Southern Europe. London: Macmillan.

King, R. and Zontini, E. (2000). The Role of Gender in the South European Immigration Model. Papers, Revista de Sociologia 60 (Special Issue: Inmigración femenina en el sur de Europa): 35-52.

Leslie, D. and Lindley, J. (2001). The impact of Language Ability on Employment and Earnings of Britain's Ethnic Communities. Economica 68(272): 587-606. doi:10.1111/1468-0335.00263.

Lim, L.L. (1997). Flexible Labour Markets in a Globalizing World: The implications for International Female Migration. Paper presented at IUSSP XXIII International Population Conference, Beijing (China), October 11-17 1997.

Mahuteau, S. and Junankar, P. (2008). Do Migrants Succeed in the Australian Labour Market? Further Evidence on Job Quality. MPRA Paper 8703.

Massey, D.S. (1990). Social Structure, Household Strategies, and the Cumulative Causation of Migration. Population Index 56(1): 3-26. doi:10.2307/3644186. 
Massey, D.S., Arango, J., Hugo, G., Kouaouci, A., Pellegrino, A., and Taylor, J.E. (1993). Theories of Internationl Migration: A Review and Appraisal. Population and Development Review 19(3): 431-466. doi:10.2307/2938462.

Massey, D.S., Arango, J., Hugo, G., Kouaouci, A., Pellegrino, A., and Taylor, J.E. (1994). An Evaluation of International Migration Theory: The North American Case. Population and Development Review 20(4): 699-751. doi:10.2307/ 2137660.

Massey, D.S., Goldring, L and Durand, J. (1994). Continuities in Transnational Migration: An Analysis of 19 Mexican Communities. American Journal of Sociology 99(6): 1492-1533 doi:10.1086/230452.

OCDE (2002). El empleo de los extranjeros. Perspectivas y cuestiones en los países de la OCDE. In: Ministerio de Trabajo y Asuntos Sociales (ed.). Perspectivas del empleo, 2001. Madrid: 333-405.

OECD (2003). Trends in International Migration. SOPEMI Report. Paris: OECD. doi:10.1787/migr_outlook-2002-en.

OECD (2008). International Migration Outlook. SOPEMI Report. Paris: OECD. doi:10.1787/migr_outlook-2008-en.

Oso, L. (2003). Las jefas de hogar en un contexto migratorio. Modelos y rupturas. In: Checa, F. (ed.). Mujeres en el camino. El fenómeno de la migración femenina en España. Barcelona: Icaria editorial: 85-104.

Palloni A., Massey, D.S., Ceballos, M., Espinosa, K., and Spittel, M. (2001). Social capital and international migration: A Test Using Information on Family Networks. American Journal of Sociology 106(5): 1262-1298. doi:10.1086/32 0817.

Parella, S. (2003). Mujer, Inmigrante y trabajadora: la triple discriminación. Barcelona: Anthropos.

Parella, S. (2009). La gestión política del género y la mujer inmigrante. In: ZapataBarrero, R. (ed.). Políticas y gobernalidad migratoria en España. Ariel, Madrid.

Parkin, F. (1978). Orden político y desigualdades de clase. Estratificación de las sociedades capitalistas y comunistas. Madrid, Debate.

Piore, M. (1975). Notes for a Theory of Labor Market Stratification. In: Edwards, R. et al. (eds.). Labor Market Segmentation. Massachusetts: D.C. Heath and Company, Lexington Books: 125-150. 
Piore, M. (1979). Birds of passage: migrant labour and industrial societies. Cambridge: Cambridge University Press. doi:10.1017/CBO9780511572210.

Portes A. and Sensenbrenner, J. (1993). Embeddendness and Immigration: Notes on the Social Determinants of Economic Action. American Journal of Sociology 96(6): 1320-1350. doi:10.1086/230191.

Reher, D. and Requena, M. (2009). The National Immigrant Survey of Spain: A new data source for migration studies in Europe. Demographic Research 20(12): 253-278. doi:10.4054/DemRes.2009.20.12.

Reher, D.-S., Alcalá, L.C. , Quiñones, F.G., Requena, M. , Sánchez Domínguez, M.I. , Sanz Gimeno, A., and Stanek, M. (2008). Informe Encuesta Nacional de Inmigrantes (ENI-2007). Madrid: Instituto Nacional de Estadística (INE), Documentos de Trabajo, 2/08.

Reyneri, E. (1996). Sociologia del mercato del lavoro. Bolonia: Il Mulino.

Reyneri, E. (2004). Immigrants in a Segmented and Often Undeclared Labour Market. Journal of Modern Italian Studies 9(1): 71-93. doi:10.1080/135457104200017 9191.

Reyneri, E. and Fullin, G. (2011). Labour Market Penalties of New Immigrants in New and Old Receiving West European Countries. International Migration 49(1): 31-57. doi:10.1111/j.1468-2435.2009.00593.x.

Rooth, D.O. and Ekberg, J. (2006). Occupational Mobility for Immigrants in Sweden. International Migration 44(2): 57-77. doi:10.1111/j.1468-2435.2006.00364.x.

Simón, H., Ramos, R. and Sanromá, E. (2011). Occupational Mobility of Immigrants in a Low Skilled Economy: The Spanish Case. IZA discussion paper 5581 March. Bonn: IZA.

Solé, C. (2003). Inmigración, mercado de trabajo y género. Documento de Trabajo, Serie Sociología S2003/01.

Stanek, M. and Veira, A. (2009). Occupational transitions and social mobility at migration to Spain. Documentos de Trabajo 4 (III). GEPS, Grupo de Estudios “Población y Sociedad” (Universidad Complutense de Madrid).

Taylor, J.E. (1986). Differential Migration, Networks, Information and Risk. In: Stark, O. (ed.). Migration, Human Capital and Development. Greenwich, Conn.: JAI Press. 
Taylor, J.E. (1987). Undocumented Mexico-U.S. Migration and the Returns to Households in Rural Mexico. American Journal of Agricultural Economics 69(3): 626-38. doi:10.2307/1241697.

Thurow, L.C. (1975). Generating inequality: mechanisms of distribution in the U.S. economy. New York: Basic Books.

Veira, A., Stanek, M. and Cachón, L. (2011). Los determinantes de la concentración étnica en el mercado de trabajo Español. Revista Internacional de Sociología Monográfico $\mathrm{n}^{\circ}$ 1: La inmigración en España: Perspectivas Innovadoras: 219242.

Venturini, A. and Villosio, C. (2008). Labour-market assimilation of foreign workers in Italy. Oxford Review of Economic Policy 24(3): 517-541. doi:10.1093/oxrep/ grn030.

Vidal-Coso, E. (2009). Activitat i complementarietat sociodemogràfica entre les dones immigrades i les no immigrades a Espanya [PhD thesis]. Bellaterra (Barcelona): Universitat Autònoma de Barcelona, Geography Department.

Vidal-Coso, E., Gil, F. and Domingo, A. (2012). La destrucción de empleo de migrantes y españoles (2007-2011): Factores demográficos, sectoriales y territoriales. Paper presented at 7th Congress on International Migration in Spain, Bilbao (Spain), 11-13 April 2012.

Vidal-Coso, E. and Miret, P. (2013). The internationalitation of domestic work and female immigration in Spain during a decade of economic expansion, 19992008. In: Oso, L. and Ribas-Mateos, N. (eds.). International handbook of gender, migration and transnationalism.Global and Development Perspectives. Cheltenham (UK), Northampton, MA (USA): Edward Elgar. International Handbooks on Gender: 337-360. doi:10.4337/9781781951477.00026.

Vono, D. and Vidal-Coso, E. (2012). The Impact of Social Networks on labour mobility: the case of immigrant's first job in Spain. Migration Letters 9(3): 237247. 
Vidal-Coso \& Miret-Gamundi: The labour trajectories of immigrant women in Spain 